Florida International University FIU Digital Commons

6-1-2009

\title{
Creating identity : the role of George Gordon, Lord Byron, in realizing the Romantic poet
}

Cristina Estevez

Florida International University

DOI: $10.25148 /$ etd.FI15101319

Follow this and additional works at: https://digitalcommons.fiu.edu/etd

Part of the English Language and Literature Commons

\section{Recommended Citation}

Estevez, Cristina, "Creating identity : the role of George Gordon, Lord Byron, in realizing the Romantic poet" (2009). FIU Electronic Theses and Dissertations. 3279.

https://digitalcommons.fiu.edu/etd/3279 
FLORIDA INTERNATIONAL UNIVERSITY

Miami, Florida

CREATING IDENTITY: THE ROLE OF GEORGE GORDON, LORD BYRON, IN REALIZING THE ROMANTIC POET

A thesis submitted in partial fulfillment of the requirements for the degree of

MASTER OF ARTS

in

ENGLISH

by

Cristina Estevez

2009 
To: Dean Kenneth Furton

College of Arts and Sciences

This thesis, written by Cristina Estevez, and entitled Creating Identity: The Role of George Gordon, Lord Byron, in Realizing the Romantic Poet, having been approved in respect to style and intellectual content, is referred to you for judgment.

We have read this thesis and recommend that it be approved.

Yvette Piggush

Andrew Strycharski

Maneck Daruwala, Major Professor

Date of Defense: June $1^{\text {st }}, 2009$

The thesis of Cristina Estevez is approved.

Dean Kenneth Furton College of Arts and Sciences

Dean George Walker University Graduate School

Florida International University, 2009 


\section{DEDICATION}

I dedicate this thesis to my immediate family and close friends. The completion of this thesis would not have been possible without their continual support, understanding and love. 


\section{ACKNOWLEDGMENTS}

No journey is ever complete without taking the time to stop and thank those who have helped you along the way. Several people deserve my gratitude and much more for the roles they have taken in my journey. My parents have always believed in me, and allowed me to go at my own pace; I am ever grateful for their undying faith in me and for providing me with faith in myself and in God. My family and friends have helped me in ways they will never know and cannot imagine, but mostly I thank them for their neverending support, especially the support they have shown in the past two and a half years.

This journey has been one of much learning, and many professors have shown me that one never really stops learning, and that one's work is never really done. The professors who make up my committee have shown me this in many ways, and they will never know the gratitude which I feel towards them. First, Dr. Maneck Daruwala, has guided me and questioned me, always forcing me to take things further. Dr. Yvette Piggush has also pushed me to be inquisitive and allowed me to run away with my thoughts for a period of time. Dr. Andrew Strycharski has provided me with room to dive into different schools of thought. Finally, there are those who, though not on my committee, have opened the doors that have led to this project. First and foremost, I would like to thank Dr. Asher Milbauer for allowing me embark on a journey to a new world. I would also like to thank Professor Barbara Weitz for guiding me on the trip that made this work possible. Finally, I would like to thank Dr. Richard Schwartz, whose guidance this semester and in the past has allowed me put my best work forward. 


\title{
ABSTRACT OF THE THESIS \\ CREATING IDENTITY: THE ROLE OF GEORGE GORDON, LORD BYRON IN REALIZING THE ROMANTIC POET
}

by

\author{
Cristina Estevez
}

Florida International University, 2009

Miami, Florida

Professor Maneck Daruwala, Major Professor

The Romantic Age in literature was a time of change and revision, especially in the world of heroes and the fictional worlds in which they lived and played. Many socalled "heroes" came into play at this time, but this was not enough for the Romantic poets, especially George Gordon, Lord Byron. The Byronic hero became the solution to the problem created by an unsatisfactory hero. In creating the Byronic hero, Byron changed literature, allowing poets and readers alike to participate actively in the processes of writing and reading. This work will examine Byron's development of his hero in Childe Harold's Pilgrimage and how other poets, such as Karel Hynek Mácha in his Maj, used the Byronic hero as a model that would help them foster a revival of both literature and nationhood. This work explores why the Byronic hero was adopted and embraced by those in England and abroad. 
TABLE OF CONTENTS

CHAPTER

PAGE

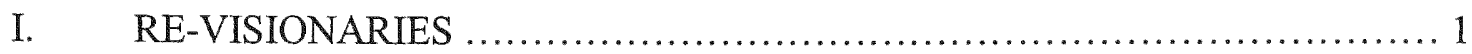

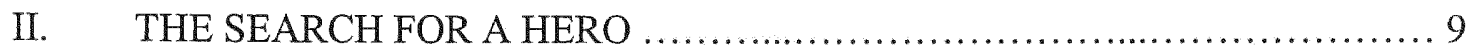

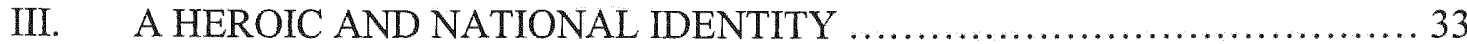

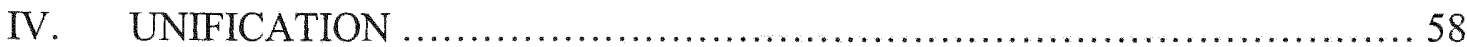

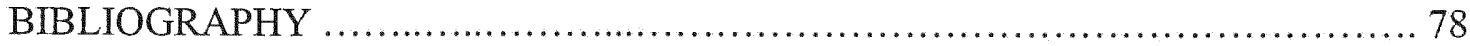


The late eighteenth and nineteenth centuries played host to what we now call the Romantic Age in literature. This age can be described as one of revision and response; the turbulent political climate provided much stimulus for the writers of the day, especially in Europe, where the birth of Romanticism occurred. Several themes persistently exist in Romanticism, but the themes of longing and searching permeate the age. George Gordon, Lord Byron, from Britain and Karel Hynek Mácha from the Czech lands are two poets for whom longing and searching were both spiritual and literary quests. These poets searched for a solution to the disillusionment caused by their respective political and social environments.

Revolutions, both political and industrial, impregnate the history of the eighteenth century. Coming out of the Age of Enlightenment, the Romantic Age was faced with the failures of the French Revolution. From the failed French Revolution came the dawn of the Napoleonic era, whose abrupt rise and fall exacerbated the paradox of the Romantic Age. With the Romantic Age came the need to be both an individual and a patriot, a cause that Lord Byron championed in his opening lines to Don Juan, "I want a hero: an uncommon want, / When every year and month sends forth a new one, / Till, after cloying the gazettes with cant, / The age discovers he is not the true one..." (Byron, I.14). If one were to search for a hero in the Romantic Age that embodied what the Romantic poets were looking for, one might choose Napoleon Bonaparte as the real-life Byronic hero. In some ways, one could argue that Bonaparte's willingness to satisfy his wants at all costs mirrors the rogue nature of Chile Harold; however, Napoleon remains an imperfect source. Bonaparte and Childe Harold are similar characters on a 
psychological level; they both have an insatiable thirst for freedom. As Michael V. DePorte comments in Byron's Strange Perversity of Thought, "He [Byron] expects irrationality and imprudence of his heroes... [Napoleon's] reforms, his wars, his crimes are alike inspired by a consuming impulse to throw off controls. Such a man hungers after a freedom that is total, a freedom that is above all unchecked from within" (405). The biggest difference between Napoleon and the hero that Byron sought is the fact that Napoleon was a military hero; one can easily plot his starting and ending points with a map of Europe. Byron, on the other hand, desired to create a hero of the mind. Napoleon's importance to Byron was restricted to his military accomplishments and his tenure as the self-named Emperor. U1timately, Byron could not model his hero on Bonaparte because his actions went against the actions that the Romantics hoped their heroes would carry out; the Romantics' heroes then were more of a revision of the classical heroes already admired by the public for their heroic deeds in reestablishing order or forcing a necessary shift in power. However, this was a vast undertaking; DePorte's assertion embodies the problem the Romantics faced, creating a revolutionary hero of their own who could renew the dated ideals of the preceding age and embrace the ideals of the new age at the same time. Rather than turn solely to Reason for answers, this revolutionary hero must turn to himself, art, nature, irrationality, desire and self indulgence to plot his course.

In order to more clearly define the role of the Romantic hero, one must first realize that the journey the Romantic hero embarks on is as much a journey of the mind and the soul as it is a physical journey. The Romantic hero dwells in the realm of the subjective; in both the poems I will examine, Lord Byron's Childe Harold's Pilgrimage 
and Karel Hynek Mácha's Máj, there is a malleability that reveals the subjectivity involved in the Romantic hero. There is a back story that grounds each text; however, the heroes of each text can serve as projections of the reader's needs and desires. That is to say that the readers of each poem have the ability to take their own subjective journey with the hero; Childe Harold and the Narrator (in Childe Harold's Pilgrimage) and the Pilgrim/Narrator (in Máj) are merely the agents of the journey. The agents acts as guides and models; it is the personal, subjective journey that the reader embarks on. The establishment of what would eventually become known as the Byronic hero, then, was a necessary practice in the art of mental and spiritual growth; for the Romantics, this mental and spiritual growth had to be achieved by travelling through a subjective realm.

Nature becomes the physical manifestation of the subjective realm that both pilgrims must travel. The pilgrims in both Childe Harold's Pilgrimage and Máj see Nature subjectively. The travelers project their needs and desires on her and she changes her role in order to fit those needs and wants. Nature often acts as a mother, guide and nurturer, but, at times she is heartless; like all mothers, Nature must look away and let her pilgrims embark on their journeys on their own. Storms and uneasy weather reflect the internal tests that each pilgrim must endure; Nature is not a foe, rather, she is a mother who must let her child grow.

The foes that would be faced by the Romantic hero would not be the monsters of legend; these foes would be internal foes. The fight the pilgrims would undertake would involve a much more terrible foe; they would have to face their internal self, and move through past and present, in hopes of realizing the potential of their future. An integral part of this experience, then, ultimately included the exploration and definition of a 
complete identity; each pilgrim was called to this journey by an internal desire to know himself and establish his identity.

Lord Byron, creator of what is now known as the Byronic hero, was one of the first to embark on this internal journey, and to do so he created his own pilgrim, Childe Harold. He began writing Childe Harold's Pilgrimage in the Levant in 1809; the first two cantos, published in 1812, gave him sudden success and notoriety (McGann, Introduction xiv). A second exile from England, this time self-imposed, yielded him the third canto in 1816, and in 1817, Byron began writing the fourth and final canto of his journey, which was published in 1818 (McGann Chronology xxv). Byron's undertaking would begin with his pilgrim, Childe Harold, and a vast journey across Europe; Childe Harold's travels are influenced by the politics of Europe, especially the Napoleonic Wars, and much time is focused on the battles of Napoleon Bonaparte and other great military heroes.

Childe Harold's search is a personal quest to find himself, as one would say these days. Childe Harold needs to find himself in order to improve himself for the better of his nation. In an early stanza, Lord Byron writes of Childe Harold

For he through Sin's long labyrinth had run, Nor made atonement when he did amiss, Had sigh'd to many though he lov'd but one, And that lov'd one, alas! could ne'er be his, Ah, happy she! to 'scape from him whose kiss Had been pollution unto aught so chaste; Who soon had left her charms for vulgar bliss 
And spoil'd her goodly lands to gild his waste,

Nor calm domestic peace had ever deign'd to taste. (Childe Harold's Pilgrimage I.5)

The above section allows for one to decide who "she" is. Childe Harold's role as a knight implies that she could be the nation. Like a young boy, Childe Harold has flirted with the nation, and, as a result, has become like a pollutant to the nation. The final two lines show that his actions have left physical damage, something that must be repaired; Childe Harold will be forced to remove himself from his nation in order to repair the injury he caused.

Childe Harold, as we are told in the beginning, is a privileged young man of good blood, whom Byron himself described as a "vagrant Childe [knight]" (Childe Harold's Pilgrimage 20) and due to his vagrancies, he is exiled and forced to go on this monumental journey. Many assume that Childe Harold's Pilgrimage was written as an autobiographical work, and whether or not this was Byron's initial intention, the fact remains that there is an emphasis on the role of the Poet in this narrative. Like Nature in Childe Harold's Pilgrimage, the Poet is to serve as a guide for the reader, leading him through foe and folly in order to help him fulfill his longing and end his search, whatever that may be. Both Childe Harold's Pilgrimage and Karel Hynek Mácha's poem, Máj, require the reader to take an active role; it is more important that the reader participate in his own subjective journey than follow the journey of the respective pilgrims.

England was not the only country within the European region where there was a search and a longing that needed to be answered. The Czech lands at this point in history were coming out of Austrian rule; the Austrian Empire's control over the Czech region 
had lasted about three centuries, and as such, the Czechs needed to recreate their own identity. Under Austrian rule, the language of the land slowly deteriorated, becoming nearly obsolete, and German became the spoken and written language. Thus, the nineteenth century brought with it the need to create a new national identity; this new national identity required the reestablishment of the Czech language, and the re-creation and growth of Czech literature. One young writer's impact on Czech culture is recognized both nationally and continentally for being an important addition to both the Czech and Romantic bodies of literature. This poet, Karel Hynek Mácha, created his own pilgrim who goes on a journey longing and searching for identity in his narrative poem, Máj. Mácha was born in 1810, and his personal journals show that he read some Byron in both Polish and German translation; his readings included parts of Childe Harold's Pilgrimage (Wellek, Macha and Byron 406). Mácha perfected his poetic style in $M a ́ j$, though his life was cut short soon after the publication of the poem (Wellek, Macha and Byron 401). Czech literature in the nineteenth century is considered to be a National Revival of sorts, but Mácha's writings show a clear understanding of and participation in the Romantic Movement. Mácha's reputation as a Romantic poet came posthumously and many scholars have devoted time to examining the parallels between Máj and Byron's Manfred, only glossing over the similarities between Mácha's poem and Chile Harold's Pilgrimage, especially in Mácha's use and development of the Byronic hero. In my examination of the two poems, I see a clear connection between these to travel narratives that I feel requires additional attention.

While there is an apparent contradiction in this case between a National Revival and participation in the Romantic Movement, the consolidation of both styles that Mácha 
achieves in Máj proves to be a necessary part of the rebirth that the Czechs participate in during the late eighteenth and nineteenth century. As already mentioned, a pronounced Czech identity was lost under Austrian rule; the Czechs had to read, write and speak in German and, with the exception of the most rural areas, the Czechs' native tongue was lost. While a national voice had to be established, one had to be aware of one's self and one's place in the world in order to be able to do so, which is where I feel the link to Romanticism comes into play. In his essay Self, Society, Value and the Romantic Hero, Frederick Garber argues that "Self-awareness, a recognition of the demands and complexities of his own private being, is, as we know, basic to the position assumed by the romantic hero" (321). Mácha shows that it is through self awareness and recognition that his pilgrim is able to become a better citizen for the nation. Upon his final visitation to the pilgrimage site, the pilgrim is revived; he "Hastens towards his goal before the sunset dies" (Mácha IV.815).

Máj, similar to Childe Harold's Pilgrimage, follows a pilgrim's voyage to fulfill his longing for a sense of self; however, this pilgrim goes on a journey to one specific site, where he recalls the story of a vagabond whose desires for love and his passions ultimately destroy his life. As with Childe Harold's Pilgrimage, the importance of the narrative lies more in the pilgrim's journey than in the story of the vagabond. The journey that the pilgrim in Máj embarks on is also subjective; the pilgrim realizes truths about both himself and his desire to see the birth of a renewed, vibrant national identity. Mácha creates a vibrant, almost human, Nature that guides his pilgrim and keeps a watchful eye on him, although at times it seems she has left him. The representation of 
Nature in Máj is like that of Childe Harold's Pilgrimage; her role as mother, guide and nurturer is malleable and varies with each part of the story.

Mácha is also creating a hero, though his hero must do more than the Romantic hero. While Mácha's hero had to do more than Byron's hero, he uses Childe Harold as a model for his pilgrim. Because of the special circumstances of $\mathrm{Czech}$ culture during his time, Mácha's hero must not only serve to heal a broken continental spirit, but he must also serve as an example of the newly created Czech persona; he must be representative of the new Czech identity, rather than a representative of the old Austrian identity that had defined them for centuries. Thus, implicit in the pilgrim's search for his own identity is the search for a singular national identity.

Both these poems, then, have a similar connection between longing and searching and the necessary involvement of Nature. Though the writers of the Enlightenment looked to Nature for rational answers, the Romantics gave themselves fully to Nature. Both these journeys, and many others within Romantic literature, emphasize a connection to water, where Nature can be at her most calm and at her most destructive. Childe Harold is not an innocent pilgrim, and although it is not stated in Máj whether the pilgrim is innocent or not, one can infer from the fact that he is on this internal journey that he is not completely innocent himself; however, it is Nature that plays the role of a forgiving mother. Nature has an important significance in both of these works. Nature is, for all her inconstancies, constant. Though Nature's actions vary through her ever changing moods, one can count on the fact that she is constantly inconstant. Nature is unpredictable, but it is because of the very fact that she is known to be unpredictable that the Romantic poets found comfort in her company. Any time of revolution is always a 
time of great change, and when those revolutions fail, the public is forced into the realization that change is scary and is not always successful. The disillusionment felt around the European continent at this time stems from the failure of change.

It is true that many of the Romantics were creating change themselves, and often times in different ways; however, by making Nature an extremely powerful, vibrant character in their poetry, and using her as their agent of change, and also using her as a guide through change, they are able to give the public the realization that a renewed sense of self was possible; the public had to commit to face their internal foes, and wallow in subjectivity until they found their way. Their government and its politics may have failed them, but the promise of Nature's guidance protects them. The Romantics know they cannot create and sustain the Movement themselves. They must rely on a tried and trusted ally in order to gain disciples. Nature, for the Romantics, is that ally. Nature's mothering role in both these poems reflects the fact that the Romantics felt the need for a nurturing figure, one that would help them grow and realize their full potential.

All of these things combined are part of what makes the Romantic Age in literature one of the most significant and popular ages. The Romantics' resolution was not to create a hero that would come and save the day. Rather, their hero would have the qualities of a rogue member of society; one could relate to this hero on many levels, and as such, was willing to trust him or her and follow his or her guidance. In Childe Harold's Pilgrimage, Byron plays around with his hero, making several models to base his pilgrim on. In Máj, the pilgrim realizes the peaks and falls of heroism through experiencing the end of the vagabond's life. These heroes, like any member of society, 
must be willing to work to attain their highest level of self; it is only then that they can truly be considered heroic. 
George Gordon, Lord Byron's literary oeuvre is filled with the search for and the creation of a new kind of hero. Years of political unrest in Europe had left many Europeans frustrated. The Napoleonic era, following the Reign of Terror almost immediately, and ending swiftly, caused much distress for the people, both in France and all over the European continent. For the Romantic poets a new literature was needed, and they revamped the classical hero into a hero that embodied their ideals and values. George Gordon Lord Byron embraced the new nineteenth century ideals; while he kept eighteenth century ideals in mind as well, he molded them to fit the parameters he had in mind for his hero. While Byron's hero shows some consideration for action, ethics and consequences, he does so in an egocentric fashion. As I will illustrate, the pilgrim embarks on a subjective journey through which he improves himself. Once he fully evolves into the self he is to become, Byron's pilgrim can advance in society.

The sense of self attained by the pilgrim comes from an increased awareness caused by a long, tumultuous journey through the internal self. The exercise in subjectivity would serve to awaken the soul and renew the spirit. For Byron, an internal search and vitality opened doors for his pilgrims (and hopefully, for his readers), both personally and socially. The traveler's voyage results in what Anne K. Mellor terms "a more open-ended, self-expanding awareness of the possibilities of life" (32). Essentially, these pilgrims are in search of improving themselves; in the case of Childe Harold's Pilgrimage an important result of this reworking of the self is the cementing of a proper, or socially acceptable, knight. Childe Harold himself is vulgar and troublesome; his subjective excursion will involve a recognition of and atoning for his sins. Byron's hero 
journeys through the subjective realm in order to improve himself both internally and externally.

Lord Byron's poetry became the vehicle with which he would create his hero and breathe new life into the written word. Rather than write a proselytizing poem that read like a sermon, Byron chose to create a hero with whom his audience could relate, that is one who was imperfect and made mistakes. According to Jerome J. McGann,

Disheartened by his world and his own inability to alter its force or circumstance, Byron creates in his poetry a drama of the disillusioned existence. Its desperation appears in an escapist gesture of a special sort: not into the future, or into art, but into the flux of everything which is most immediate, a flight into the surfaces of poetry and life, the dance of verse, the high energy of instant sensations and feelings (whether of pleasure or pain makes no difference). (Byron's Ideal of Immediacy 127)

Because Byron could do little (by choice or social position) to physically change the world in which he lived, he felt that he was obligated to create the ultimate escape, the ultimate journey on which he and his readers could both embark in order to realize something new, or if not new at least different. Byron's pilgrim, similarly, had to escape and leave hearth and home behind in order to enter the new world that would carry him to a new horizon.

If the world that Lord Byron was trying to escape within his poetry was a world framed by the rigid structure of London society, then the world that he would create would be one with few physical boundaries for the imagination. According to McGann, 
"His abandoned and sensational poetry is the reflex of the civilization which created the necessity for such a style of life and art" (Byron's Ideal of Immediacy 130). In essence the literary actions that Byron and his contemporaries take come as a reaction to some of the limitations of the previous age. Such limitations, especially those in the domestic realm, or England, could no longer be paid attention to. In order for the Romantic poets to be successful in their mission of creating a new literature, they had to abandon the constraints of the domestic world. In essence, they had to create a new world in which the possibilities stretched further than the mind; in this world, the lines between history and fiction blurred, allowing for the recreation of stories of old, in essence, renewing them. They felt that they had to create for their readers an adventure that could transcend the boundaries of everyday life; in short, Byron and the other Romantic poets had to create a literature that allowed them to suspend reality and depend on belief in the extraordinary.

As with all poets, Byron practices creation in his poetry, Childe Harold's Pilgrimage being no exception. Byron had to ensure that his pilgrim left home, left England, allowing him to embark on a ride through Europe's history. Byron recreates Europe in his own terms in this narrative; he creates

... a poem of unconventional travel and exile, a poem whose scenery is that of Europe, and more particularly a Europe defined by two distinct features: its history, and its boundaries. The first two cantos of Childe Harold construct a world riven by political and military strife that is bounded by regions of wilderness and exotic barbarism. This is a new world for the Romantic poet, or indeed the popular poet of the opening 
decade of the nineteenth century, and it was one that Byron made his own, and in a way, never left. (Martin 78-79)

Byron creates a strong connection to the history of Europe; the connection with Europe that Byron creates for his pilgrim shows that one must look to the past in order to progress. In order to keep his readers interested in history, he creates an adventure for them.

Lord Byron's narrative poem, Childe Harold's Pilgrimage, creates that adventure. Mirroring Byron's own journey throughout Spain, Portugal, the Mediterranean Sea and its surrounding countries, such as Greece, Italy and France, Childe Harold becomes the solution to a complex and deep-seeded problem. The pilgrim was not, according to Lord Byron, "...intended as an example, further than to show that early perversion of mind and morals leads to satiety of past pleasures and disappointments in new ones, and that even the beauties of nature, and the stimulus of travel (...) are lost on a soul so constituted, or rather misdirected" (Addition to the Preface [to Cantos I-II] 21). Byron's words, written almost as a disclaimer to those expecting a hero of moral and knightly countenance, show that his hero (who would become known as the Byronic hero) had no heroic qualities at all. Marilyn Guall echoes this sentiment in considering the Byronic hero:

The 'true' hero, the individual endowed with superior talent, insight, character, will, eloquence, intellect, courage, was unable to perform that public action by which heroism is realized because he was crippled by the institutions where power resided or collective life where it was coming to reside" (The Byronic Hero 169). 
Guall argues that standards and accepted norms are what held the "true" heroes back from fulfilling their missions. The Byronic hero's escape is what allows him to act freely, and therefore become the hero that the Romantics wanted.

Throughout Childe Harold's Pilgrimage, we see Byron tinkering with his hero; the course that the pilgrim embarks on can be seen as his movement towards becoming Byron's ideal hero. To begin with, Childe Harold has all the faults and flaws of any member of humanity; he is not the stereotypical hero who, in essence, was forced into failure. Essentially, the hero's failures come as a result of the choices he makes regarding action and inaction; it is up to the Byronic hero whether or not he will succeed or fail. Rather, Byron's pilgrim is one modeled from many of the qualities and frustrations that could be found in the sociopolitical climate of his day. The pilgrim was not programmed to do good deeds and save the world; his pilgrim was a young frivolous boy who did little to ensure his heritage and title, making Childe Harold a man whose proud familial history had been erased by his faulty actions:

Childe Harold was he hight: - but whence his name

And lineage long, it suits me not to say;

Suffice it, that perchance they were of fame,

And had been glorious in another day:

But one sad losel soils a name for aye,

However mighty in the olden time; 
Nor all that heralds rake from coffin'd clay,

Nor florid prose, nor honied lies of rhyme

Can blazon evil deeds, or consecrate a crime. (Childe Harold's Pilgrimage I.3)

It was important for Byron to produce an anti-knight, or a knight who possessed no knightly qualities. In doing so, he created a hero who was on a par with the middle to lower strata of society, one with whom they could identify. If Byron had modeled a hero that was a member of the general public, than the general public could essentially decide whether or not they wanted to join his pilgrim on his journey, or forge their own in search for a solution to their own longing.

It is never revealed whether or not Childe Harold had any specific sites to see, or any specific goal to attain on his journey. The importance of Childe Harold's journey is the process of self-realization and self-actualization. While his personal intentions remain unclear, as we have seen, inherent in any subjective course is the cultivation of an improved inner and outer self. Childe Harold is a reflection of the general public; his longings cannot be defined, because ultimately, they become those of his followers. In other words, the pilgrim longs for what one longs for. In order to fulfill the escapist notions that McGann refers to, Byron could not have molded his pilgrim with many specifications. One cannot escape into someone else's fantasy, just as one must be the master of his or her own longings and desires.

Lord Byron ensures that his audience is aware of his desire for an active participation in his narrative journey. For the first half of the narrative, Childe Harold 
will suffice as the necessary pilgrim. The second half of Childe Harold's Pilgrimage

begins with an address to Greece that can be read as a request for followers:

Yet to the remnants of thy splendor past

Shall pilgrims, pensive, but unwearied, throng;

Long shall the voyager, with th' Ionian blast,

Hail the bright clime of battle and of song;

Long shall thine annals and immortal tongue

Fill with thy fame the youth of many a shore;

Boast of the aged! lesson of the young!

Which sages venerate and bards adore,

As Pallas and the Muse unveil their awful lore. (Byron II.91)

The call for pilgrims heeds a warning that the remainder of the journey will be as difficult as it is promising, though one should not despair. They must remember Childe Harold and join his pilgrimage; Childe Harold must serve as a model for the new pilgrims. Just as his story is recounted, so will theirs be, provided they follow the model he has given. Each one who is willing to join the pilgrimage must come on his own and give himself over to the promise of a new being. Because the pilgrimage is an internal experience, these pilgrims, as well as Childe Harold, must break free from anything that can impede their progress, including others; the pilgrimage had to be a solitary adventure. 
It is also important that Childe Harold's journey be a solitary one. He leaves behind everything he knows; he leaves his father's vast fortunes, and those who made up his father's court, although he barely knew them. In short, he leaves his past life and identity behind; this is a journey he must make by himself in order to become new. While the openness of Byron's texts allows his audience to take the journey with Childe Harold, in order to appreciate the text fully, one must make that journey on his own. The reader can pose his own thoughts and longings on Childe Harold's, but he should do so in a manner that remains his own, allowing him to recognize himself fully. He must give himself body and soul and pay little mind to Reason and Rationality, which can impede his journey and force him to make the wrong choice.

Though Byron did embrace some eighteenth century values, he did not preach of a strict adherence to Reason as a motivator. As Childe Harold's Pilgrimage created a world that required a belief in the ability to redefine history, reliance on Reason could prove dangerous to Byron's captive audience. He would not lecture of the importance of Reason over personal wants and needs; ignoring one's longings and desires could lead one to feel unfulfilled; therefore, it was time to give in to the search for fulfillment. His philosophy had a dual effect; on the one hand, it allowed for the creation of new desires and dreams. Secondly, inherent in the aim to fulfill one's longings was the willingness to undertake a personal journey similar to that of the pilgrim, the willingness to give oneself over fully to the cause of one's own self-improvement. Though this journey implied great risk, it also generated great promise; whether or not one got the answer he thought he was looking for, he, like Childe Harold, would undergo personal experiences, losses, 
and triumphs that would undoubtedly reshape one into a better version of his previous self.

Achieving the goal of self-improvement was not an easy task, and Byron made sure that his pilgrim experienced hardship along the way; he did not want to give false security to those who were willing to take on this new course in life. It was necessary for Childe Harold to have great faith while on this journey, though not a faith in the religious sense. The belief in a religious deity is replaced in this narrative; rather than have his pilgrim believe in God Byron makes Nature the highest deity that his pilgrim must worship. Nature will serve as his only guide; therefore, the pilgrim must give himself to her body and soul. Several incantations are uttered on behalf of Nature, the first of them being:

Dear Nature is the kindest mother still,

Though always changing, in her aspect mild;

From her bare bosom let me take my fill,

Her never-wean'd, though not her favour'd child.

Oh! she is fairest in her features wild,

Where nothing polish'd dares pollute her path:

To me by day or night she ever smil'd

Though I have mark'd her when none other hath. 
And sought her more and more, and lov'd her best in wrath. (Byron Childe Harold's Pilgrimage II.37)

These lines show several things. First, they show that Nature is something that must be revered, whether she remains the same or changes. Secondly, it shows that Nature will always be there, even if one loses faith in her; this reminds one of a godly figure. Finally, the line "...Though I have mark'd her when none other hath," (Byron Childe Harold's Pilgrimage II.332) shows that the pilgrim has hurt her in fits of passion, but realizes that he must trust her so willingly that he is putting his whole life in her hands. Throughout his journey, Childe Harold will face moments of peace and light and turbulent storms and darkness.

Nature, as the guide that Childe Harold must rely on throughout his journey, can be seen as many things, but the most important role that Nature has in Childe Harold's Pilgrimage is the role of guide and mother. In her mothering role, Nature will have to guide and help Childe Harold, but she also has to let him go and survive experiences on his own. Just as any mother must do for her own child, Nature must give her Childe a strong base on which he can rely in order to become himself as fully as possible.

The physical topography of Childe Harold's journey is just as varied as Nature's roles in this narrative. Traveling through the Mediterranean, Childe Harold faces an exciting new world, different from his natural habitat. Each stage of the journey presents a new experience for him, revitalizing and renewing him, making him ready to continue. The newness of the experience excites the pilgrim:

Now Harold felt himself at length alone, 
And bade to Christian tongues a long adieu;

Now he adventur'd on a shore unknown,

Which all admire, but many dread to view:

His breast was arm'd 'gainst fate, his wants were few;

Peril he sought not, but ne'er shrank to meet,

The scene was savage, but the scene was new;

This made the ceaseless toil of travel sweet,

Beat back keen winter's blast, and welcom'd summer's heat. (Byron Childe Harold's Pilgrimage II.43)

Reading these lines, one can see a fresh-faced, relaxed young boy, ready to face the world. He has dismissed his Christian values and is beginning anew. Childe Harold has a renewed innocence, which is necessary to begin on this next leg of his journey. The time has progressed to summer, when Nature is full and vibrant, lending herself to Childe Harold. From Nature, Childe Harold can gain this renewed innocence and excitement, he is ready to move on.

Childe Harold is left looking forward to the future. During the first part of his journey, he experienced the history of the lands he visited; he has learned of failures and successes, of tears and celebrations. His most important lessons come from seeing what lurks in waiting for the imprudent and careless:

But all unconscious of the coming doom, 
The feast, the song, the revel here abounds;

Strange modes of merriment the hours consume,

Nor bleed these patriots with their country's wounds:

Not here War's clarion, but Love's rebeck sounds;

Here Folly still his votaries enthralls;

And young-eyed Lewdness walks her midnight rounds:

Girt with the silent crimes of Capitals,

Still to the last kind Vice clings to the tott'ring walls. (Byron Childe Harold's Pilgrimage I.46)

The above lines, a small example of all that Childe Harold has experienced on his journey also show the dangers of acting without caution or care. As Folly and Lewdness continue to dance, Danger lurks around the corner, watching and waiting, realizing that his time to strike has come. The revelers have ignored the signs and have continued on their reckless journey. The example of the revelers' story can serve as a warning to Childe Harold; though he has dedicated himself body and soul, the pilgrim must stay on his course and not be distracted by the fooleries of revelry.

The successes and failures of history serve as a means by which the pilgrim will learn how to shape his new self. While folly can be dangerous, extreme prudence can be as well; Childe Harold must learn that there is a necessity for balance. It is only through balance that one can remain centered on his goal. He must not be distracted by the 
diversions that he will experience on his journey; just as he moved on from the scene of Folly and Lewdness, he must continue to move beyond those who will attempt to distract him. As any pilgrim will face the temptations of laziness, tiredness, solace and longing, Childe Harold will encounter these throughout his journey. He must not succumb to them in order to be successful in his search. He also cannot be weary. He must retain the attitude of the pilgrim seen above; returning to his journey, for it is unknown what will await him:

What is the worst of woes that wait on age?

What stamps the wrinkle deeper on the brow?

To view each lov'd one blotted from life's page,

And be alone on earth as I am now.

Before the Chastener humbly let me bow:

O'er hearts divided and o'er hopes destroy'd,

Roll on, vain days! Full reckless may ye flow,

Since Time hath reft whate'r my soul enjoy'd, And with the ill of Eld mine earlier years alloy'd. (Byron Childe Harold's Pilgrimage II.98)

The pilgrim has to be ready to continue on his journey. The reader must be ready to experience what is to come. The above lines can also serve as a faithful proclamation of readiness for the future; those following this journey that have become tired and wan can 
read these words and realize that Childe Harold had to endure hardships on his journey, and therefore become willing to continue on this journey upon the return of their pilgrim, Childe Harold.

After a span of about five years, and during a second exile from Britain (coming as a result of the scandalous affairs of his love life), Byron picked up again with his beloved Childe Harold, this time bringing to us an older, more experienced, and in some ways, more down-trodden pilgrim and Narrator. The pilgrim continued his adventure throughout his departure, and as the Narrator shows us, is somewhat worse for wear:

Long absent H A R O L D re-appears at last;

He of the breast which fain no more would feel,

Wrung with the wounds which kill not, but ne'er heal;

Yet Time, who changes all, had altered him

In soul and aspect as in age: years steal

Fire from the mind as vigour from the limb;

And life's enchanted cup but sparkles near the brim. (Byron Childe Harold's Pilgrimage III.8.66-72)

Having continued on his personal odyssey, this time without an audience, Childe Harold has become eternally scarred by some of what he has seen and done. His lonesome journey has left him weary; he is losing that youthful swagger with which he began this journey. 
Though he is weary and blemished from his difficult progression, Childe Harold cannot give up, and must find it within himself to advance. He must dig deep to once again find that young boy whom we first met, and bring him to mind in order to not lose will or strength. The Narrator describes the plight of our drained pilgrim, showing sympathy for him and his plight. It is not Nature that Childe Harold turns to; she has been his guide long enough, and has left him to journey on his own, as a mother should with her child. Childe Harold is left to make his progress on his own, and Nature is made to watch and hope that he will continue to progress and find his way.

Now the pilgrim must rely on the excitement of new experiences to ensure that he does not abort his mission. As he travels on, with his thoughts to keep him company, Childe Harold comes upon the remains of an empire that awakens his slumbering soul:

Stop! - for thy tread is on an Empire's dust!

An Earthquake's spoil is sepulchred below!

Is the spot mark'd with no colossal bust?

Nor column trophied for triumphal show?

None; but the moral's truth tells simpler so,

As the ground was before, thus let it be; -

How that red rain hath made the harvest grow!

And is this all the world has gained by thee, 
Thou first and last of fields! king-making Victory? (Byron Childe Harold's Pilgrimage III.17)

The promise of a buried empire has renewed Childe Harold's spirit and sparked his interests once again. He has landed on Waterloo, the home of that famous battle that ended Napoleon's tyrannical rule. Buried under the dust are the remnants of the French Empire: the stories of a troubled empire and failed revolution.

There, Childe Harold sees that storied fight in the remnants of that ruined site. He experiences joy and the sound of a revived spirit:

There was a sound of revelry by night,

And Belgium's capital had gathered then

Her Beauty and her Chivalry, and bright

The lamps shone o'er fair women and brave men;

A thousand hearts beat happily; and when

Music arose with its voluptuous swell,

Soft eyes look'd love to eyes which spake again,

And all went merry as a marriage-bell,

But hush! hark! a deep sound strikes like a rising knell! (Byron Childe Harold's Pilgrimage III.21) 
The preceding lines show what invigorated Childe Harold. Once he discovered that he was in such an historic place, he felt the jubilation of the inhabitants and took an exhilarating breath. Just as quickly as he felt the rush of a celebration, the "...deep sound" strikes again, reminding him of what is to come; the cannon at a steady beat strikes with fury (Byron Childe Harold's Pilgrimage III.21.189). The rise and fall of action and emotion resembles the peaks and pitfalls of his journey. The weary wanderer is given a momentary reprieve; he is again thrust into the ebb and flow of his journey, which is sometimes forgiving and sometimes harsh. Though our pilgrim has aged and advanced in his journey, there is still work to be done. He must press on, wallowing in the subjectivity of his own self.

Again, Childe Harold will exit the narrative for a period of time. As one chapter finishes, and another one begins, it is time for our Narrator/poet to take the wheel as a reminder of how close the pilgrim is to his goal. Nature has left the pilgrim to himself, and now it is time for his audience to do the same. The Narrator/poet, as the archetypal Byronic hero, will now be our guide. The worries of the pilgrim have long passed him. The pilgrim is on a search for himself, desiring to become the most complete version of himself; the Narrator/poet, having become the most complete version of himself is no longer plagued by the contemplations of the unfulfilled mind. He is at peace with his responsibilities; if he were not, he would not be able to function as our guide.

The poet also comes into play in the narrative, reminding the reader that an active participation is necessary for all players, including both the poet and his audience. While the Narrator/poet has always been in the narrative, his voice is now more defined. He has journeyed as Childe Harold has, and consequently, has gone through the same pain and 
pleasure the pilgrim experiences. Mellor states, "The stormy, often painful mental passages of the poet-narrator finally led him to a growing consciousness of the possibilities of life" (33). The internal journey has been as difficult as the external journey, but the Narrator/poet has realized, as the pilgrim soon will, that the pain he has experienced reveals newfound possibilities. Mellor goes on to quote one of Lord Byron's letters to Annabella Milbanke: "I can't stagnate... if I must sail let it be on the ocean no matter how stormy - anything but a dull cruise on a level lake without ever losing sight of the same insipid shores by which it is surrounded" (32). The excerpt from Byron's letter shows that the Narrator/poet has the same faith in Nature that his pilgrim has. Again, any pilgrim willing to go on this journey must resolve to continue on this journey no matter what conditions he may face, his determination will see him through. The Narrator/poet will lead the reader through the next part of the voyage, showing them the influence of the passage of time.

The Narrator will remain limited in what he shows his audience. He remains a mysterious being; the Byronic hero wraps himself in the cloak of mystery. Unlike the conventional hero, the Byronic hero does not rely on the glory showered on him by others because of his heroic deeds. He does not look for glory in his current state of being; the Byronic hero knows that his dues will be paid in time. He is quiet and precise. At most, the Narrator keeps an arrogant air about himself; though he never says so outright, he holds himself to a higher standard than he does most.

His slow narration shows some, though not much, of his own personal pilgrimage. In following Childe Harold's own travels, he has fallen again on the lands he once explored. As he moves past them, he glimpses over his life, he remembers that he, like 
Childe Harold, abandoned his past life. His journey led him to learn new languages, become one with various village peoples and immerse himself in his being. He is no longer affected by change.

At one point, he wonders of that past life; though he has completely detached himself from it, he still wonders, possibly hopes, that he will have some association with it in his death. He wants to come home, though it has not been his home for a long time:

Perhaps I loved it well: and should I lay

My ashes in soil which is not mine,

My spirit shall resume it- if we may

Unbodied choose a sanctuary. I twine

My hopes of being remembered in my line

With my land's language: if too fond and far,

These aspirations in their scope incline, -

If my fame should be, as my fortunes are,

Of hasty growth and blight, and dull Oblivion bar

My name from out the temple where the dead

Are honoured by the nations- let it be-

And light the laurels on a loftier head! 
And be the Spartan's epitaph on me-

'Sparta hath many a worthier son than he.'

Meantime I seek no sympathies, nor need;

The thorns which I have reaped are of the tree

I planted, - they have torn me, - and I bleed:

I should have known what fruit would spring from such a seed. (Byron Childe Harold's Pilgrimage IV.9-10)

The above stanzas show a shift in the Narrator's longings. He has fulfilled his mission to become his fully developed self; however, there is a longing for the time he sacrificed. Time has progressed without him; in looking back on his journey, the Narrator/poet realizes that things have continued without him. His longing is no longer one that must be answered. It will remain there for the hero knows he has made an appropriate sacrifice. In leaving his home for so long, he, in essence has turned his back on his heritage, and it has done so with him. Again, it is not a longing that can be taken care of; it is a direct result of his choice to partake in this journey. The preceding lines, perhaps, serve as a warning of what is to become of Childe Harold once he completes his journey; he will, at some point, realize the cost of his sacrifices, and have to decide if it was all for naught. The passage shows that for the Narrator/poet the journey was worth it; the ramifications of his decision to complete his own pilgrimage outweigh the sacrifices he made in order to do so. 
The Narrator defends his choice, realizing that although he gave up much to go on this journey, his life has not been void; in fact his life is much more complete for having gone on his journey. Perhaps he has not only gone on this journey with Childe Harold to guide him, but also to remember what the journey was for him, and realizes the significance of such a voyage. We see that as the Narrator is nearing the end of this passage of remembrance, he looks on it fondly:

But I have lived, and have not lived in vain:

My mind may lose its force, my blood its fire,

And my frame perish even in conquering pain,

But there is that within me which shall tire

Torture and Time, and breathe when I expire;

Something unearthly, which they deem not of,

Like the remembered tone of a mute lyre,

Shall on their softened spirits sink, and move

In hearts all rocky now the late remorse of love. (Byron Childe Harold's Pilgrimage IV.137)

The lines express a sense of complete fulfillment. The journey has left a spark in him that cannot be diminished by illness or death; it will live longer than him and remain a part of him. The passage shows what a spiritual experience he has gone through; first, his own journey made him complete, and this second adventure, though as the guide instead 
of the pilgrim, has renewed his sense of fulfillment, curing the longing that he once felt for the sacrifices he made. The Narrator's renewed sense of fulfillment bodes well for the pilgrim; one is left to hope that although the voyage is rough and long, what results from it is, in fact, of more worth than one can expect. The transcendental journey brings a sense of immortality to the Narrator, allowing him to act without fear and longing.

We see that the Narrator was successful in his quest, but the question of the pilgrim's own success remains. The Narrator/poet seeks the pilgrim, wondering of his progress:

But where is he, the Pilgrim of my song,

The being who upheld it through the past?

Methinks he cometh late and tarries long.

$\mathrm{He}$ is no more- these breathings are his last;

His wanderings done, his visions ebbing fast,

And he himself as nothing: - if he was

Aught but a phantasy, and could be class'd

With forms which live and suffer - let that pass -

His shadow fades away into Destruction's mass. (Byron Childe Harold's Pilgrimage IV.164) 
The Narrator/poet sees the pilgrim, who is still travelling. He feels that the pilgrim is nearing the end of his journey, and bids adieu to the pilgrim.

Lord Byron recognizes the people's desire and longing for a new hero, one who represents them and can lead them out of their despair. In Childe Harold's Pilgrimage, he creates that hero; this hero is imperfect, and one that will continue to be developed as time progresses. Though Byron's narrative is not didactic in nature, he implicitly leaves his audiences with certain messages; in essence, Lord Byron, through his narrative, is the guide that will lead the people away from their desperation and into a brighter future. 
In 1810 when Byron was twenty-two years old, Karel Hynek Mácha was born in the Czech lands. The Czech region, known as Bohemia at that time, was beginning to emerge from the rule of the Austrian Empire, a rule that had lasted nearly three hundred years. The Czech citizens were called upon to create a nationalistic literature that reestablished their identity as a formidable nation-state. Twenty six years later, shortly before his own death, Karel Hynek Mácha wrote a poem, Májj, that would fulfill such a requirement. The authorship of Máj gave him the honor of being considered the region's most successful Romantic poet.

One may feel that the resurrection of a folk tradition would be the place to start in order to create a new national literature, and the Czechs felt the same initially; however, their attempt to recreate a national literature based on folk tradition failed upon the discovery of forged manuscripts. In 1817 and 1818 respectively, the Královedvorský and Zelenohorský documents (collectively known as the RKZ documents) were discovered in Bohemia. These documents were believed to be medieval manuscripts. They were an important find as they would be used to teach the Czech citizens of their lost history, a point essential in the re-building of a nation. Andrew Lass argues, "With an education in things Czech, the individual would become a member of a nation whose history, once written, would amount to a national victory" (459). Such a victory was imperative for a region like the Czech region because their history had long been quieted under Hapsburg rule. Consequently, the finding of medieval manuscripts held great promise for the Czech people, and possibly restored their faith in the ability to rebuild their own nation. These documents were met with some skepticism, however. "They had a key role in the 
formation of Czech Romanticism, but the nationalistic sentiment they raised gave rise to was centered as much around their questionable authenticity as around their undeniable aesthetic value" (Lass 458). While these manuscripts were artistically valuable, their uncertain authenticity proved that these manuscripts would not provide the Czechs with the literature they needed.

During the early $19^{\text {th }}$ century, several more medieval documents were found, including Visherad Song in 1816 and Libuše's Oracle in 1848, though the authenticity of the RKZ documents was continuously questioned. Václav Hanka, a struggling poet, was one of the people constantly associated with the finding of the documents, and in 1818 , Josef Doborovksý accused him of forging the Zelenohorský manuscripts (Lass 460). Accusations against Hanka continued even after his death in 1861 and it was not until the 1880s that Masaryk, a Czech historian and editor of the joumal Atheneum verified that they were, in fact, forgeries (Lass 460). Though these documents were forged, the Czechs still kept them as part of their literature, but considered them " ....literary masterpiece[s] of little historical value" (Lass 460).

Though Doborovskýs tests seemed to prove the manuscripts were forgeries, according to Lass, speculation continued throughout the $19^{\text {th }}$ and $20^{\text {th }}$ centuries; some people still considered the forgeries to be true documents, while other people speculated that the Austrians had concocted the whole ordeal as a means to regain control over the Czech population (460). Ultimately, the Czech's literary revival was tainted, and therefore they had to work twice as hard in order to gain a strong foothold as a powerful European country; the Czechs had to be saved from the scandal of these manuscripts. 
Like those who were taking part in the Romantic Movement in the United Kingdom, the Czechs were also looking for a hero. The Czech hero, as it was, had to satisfy a deeper longing than that for the Romantic hero. While other Romantics longed for an anti-hero that would serve as the subject for a renewed literature, the Czechs needed a hero who would establish a Czech national identity as well as influence a new literary tradition. Mácha chooses to answer this yearning in a way similar to Lord Byron; in $M a ́ j$, a narrative poem, we see a pilgrim on a quest for the inspiration to develop and maintain a national identity that he and his people could be proud of. The pilgrimage involves both a return to the past and an interior search, similar to that of the Narrator in Lord Byron's Childe Harold's Pilgrimage. From Mácha's journals, we have found that he had read portions of Childe Harold's Pilgrimage in German and Polish translation, and copied passages in English, although he did not speak the language, so he was aware of Byron's literary goals (Wellek, "Mácha and English Literature" 155). Like Byron, he employs both Nature and the Narrator to a great degree, emphasizing their importance in the course of the narrative. Nature and the Narrator serve as reminders of the longing for a national identity and the importance of striving to fulfill it.

While Czech literature was going through a Nationalist Revival period during the nineteenth century, Mácha employs many of the Romantic notions popular across the Western world, and as such is able to span both the parameters of Nationalism and Romanticism with $M a ́ j$, which is widely considered to be his greatest poetic work. It is this fusion of Nationalism and Romanticism that takes Byron's hero one step further; Mácha's hero was to become an establishment in the new literature, as well as a national symbol, at home and abroad. 
The influence of Romanticism was widespread throughout Europe, and, as already noted, the Czech region was no exception. Mácha used Byron as a model for much of his poetry, and Byron's influence on him is clear within Mácha's texts. While Mácha could have kept his writing in the Romantic style without imitating Byron, his choice to imitate one of the best known Romantic poets proved successful for Mácha. René Wellek, a Czech literary critic who worked extensively with the literature of Karel Hynek Mácha claims that

Mácha was the first subjective poet of the Czechs, the first to express an intensely personal view of life, the first in whose hand the language began to sing in subtler tones than in those of the folk song or academic classicism, the first who created metaphors for their own sake, the first whose imagination touched the highest topics of life and death, nature and the human soul. (400)

In Máj, Mácha created for his pilgrim a journey similar to that of Childe Harold's; the differences between the two journeys (this journey takes place on land, and runs only through the Czech region; the past that is revealed is not that of the country's history, rather it is a personal tale about love and loyalty) are what made Máj a poem that reflected the new Czech identity.

In his efforts to create a literature that was Romantic and Nationalistic at the same time, then, Mácha uses the structure Byron provides and ingredients that are solely Czech, allowing him to create poetry that can be and is considered invariably Czech. Wellek proceeds to say: 
But his role was not merely historical in breaking down barriers or preparing the soil. His poetry is alive today for its own sake, for its music, imagination and power of thought, which far transcends the common label of Byronism with which he used to be praised and derided in turn (400).

Even in translation, the vibrancy of Mácha's words comes through; as Wellek suggests, Mácha's words have a lyrical quality to them of their own. Though Wellek prefers that Mácha be dealt with separately from Byron, the connections between the two poems are worth examination; they are clear, even in translation, where the weight of words is often lost.

Mácha's poem begins with an invocation that describes the Czech people, or rather, as the Narrator hopes the Czech people will be seen: amicable, strong and loyal. The invocation serves a double purpose; the first shows non-Czech readers what the Czechs are as a nation, and the second is to inspire the Czech readers to be proud of their nationality, and to embrace the Czech heritage. One of the last stanzas of the invocation shows this desire to regain a Czech national identity:

You are the Czech tribe's faithful son,

Faithful brother to your brothers;

The Czech tongue is to you as well

Your fathers' dear inheritance.

The Czech hills - the Czech vales - 
The Czech fields - the Czech grove -

The whole wide country - this Czech land

Is your dearest paradise. (Mácha 31-38)

The stanza shows the importance the Narrator feels that nationalistic pride carries for the Czech people. It is time to reclaim their national identity, and to embrace the topography of their own land. Here the nature that makes up the Czech lands is celestial, paradisiacal. The Narrator wants his readers to feel that they are in paradise. The Czech language, according to the Narrator, is something to be cherished as well; though the Czech language was not altogether lost during the Austrian rule, German did become the predominant language, both in oral and written terms, as well as in education. The Czech language had begun to be reclaimed during the Age of the Enlightenment; Mácha felt that he needed to use his poetry as a reminder of the necessity of embracing the Czech language. A country's national language is as important as its national identity, and so it is the Narrator's job to reinforce the importance of embracing and reviving the Czech language.

The inextricable unity between a nation and its language is something that the Czechs had to embrace; if they did not regain their language, then they would not (at least in the eyes of the outside world) be a true nation. According to Hugh LeCaine Agnew, this was a problem the Czechs faced. It was once thought that the Czech language had to be embraced by the highest of the social strata in order for it to trickle down to the less privileged and become, once again, the language of the nation. Agnew contends, "Yet as long as nation remained a primarily political concept, Czech would not be a national 
language unless the foremost members of society, those with political rights, used it hence the concern of the defenders of the language for the social status of Czech and their efforts to encourage especially the nobility to use it" (68). Mácha's urgency in calling to his reader to embrace the Czech language becomes even more important. Mácha, by including this reminder to his readers, brings in the middle and lower classes as well. Essentially, any Czech person who reads Máj is called upon, by the invocation, to embrace the Czech's culture, history and language. Mácha, in reaching to a national audience through his invocation is ensuring that the nation as a whole takes a participatory role in Czech life.

The re-creation and sustenance of the Czech language became important not only on the international stage, where the Czech lands were once again being recognized as a nation, rather than part of an empire, but also locally, as it worked to increase the pride the Czechs felt in their nation. The new language had to be spread across the entire mass of the Czech lands. The lack of motivation on the part of the nobility to embrace the new language forced those outside of the upper class to adopt it; because of this, all the citizens of the region would be held responsible for the reestablishment of a Czech national identity. According to Agnew:

The nation would not die as long as someone continued to speak Czech, even if the nobility did not. The heritage of the great Czechs of the past was for all Czech speakers, who were the "descendants" of these patriots, whatever their family tree from generation to generation. But if the Czech nation were to take its rightful place among the nations of the world, 
then...patriotism demanded that the Czech language take over all the functions of a modern, national language. (69)

Agnew's statement shows in several ways that a new order was being formed in the Czech lands during this period of change. The new order was not necessarily dependent on the higher classes; rather the middle and lower classes were called upon to become independent of the nobility's example for the benefit of the nation.

The dependence on the common people of the Czech lands creates the necessity for the combination of both an individualistic and nationalistic nature. One had to be dependent on oneself, but he must not be selfish, for those who are selfish do not work for the common good of the people. Nature, as Mácha quickly reveals, is subject to this as well; all realms of Nature must perform their prescribed duty in order to not disrupt the cycle. According to the Narrator, when the moon disrupts the cycle, she dies:

And their [the suns] worlds the heavens shining

As to love eternal's temple rose;

Until - aflame with mutual passion

Transforming into dying sparks -

Like wandering lovers they conjoined.

The full moon's face so beautiful -

So palely bright so brightly pale,

Like lover seeking her beloved - 
Flamed into a rosy glow;

Her watery images she espied,

And there for love of self she died. (Mácha, I.15-25)

The above excerpt shows that during the twilight hours, the moon and the sun become one, and generally, the sun will eventually leave the moon alone in her station, but something has prevented this from happening. The moon has focused on fulfilling her personal desires, rather than complete her prescribed task; this is meant to show that those who wish to revive a nation must put that desire before their own personal desires.

Bronislava Volek, in an essay entitled Expressive Elements in Mácha's May and in his Diary and Letters, argues that the above excerpt shows the conflict that is created when the citizens of a nation have to choose between their longings and those of the nation. In essence being self-indulgent can effectively eliminate the dreams for a unified and glorified nation expressed in Mácha’s Máj. Volek claims that passage from Máj

...reflects both Mácha's poetic style and the existential dilemma of his life. An intense and all-encompassing eroticism characterizes virtually all of the nature passages of May and conveys a sense of infinite longing, but it is invariably accompanied by motifs of human destruction, hatred, misery, disappointment, violence, ruin, torture, death and sorrow. The contrast is devastating. (350)

Volek's grim description of the crisis found within Máj suggests that, ultimately, it is the human condition that will keep the nationalistic ideal from being realized. Like the 
moon, when one works with egocentric motives, he or she sets himself and those dependent upon him up for failure. The contrast of the beautifully written poetry and the violent subject matter embedded in it serves as a warning to those reading it that they should keep the national identity at the forefront of their thoughts, and work for the progression of the nation. The complex narrative creates an important function for the pilgrim: the pilgrim must travel to the site to experience Jarmila and Vilém's tale in order to ensure that he will be able separate himself from his self-centered desires.

In his journey, the pilgrim goes to one pilgrimage site, a lake in the Czech lands (now called Mácha's Lake), where he comes to learn the story of Jarmila and Vilém, two ill-fated lovers whose longing for each other ultimately brings about the other's death. Vilém is a vagabond, a bandit who left home as a young man; Jarmila is a beautiful young girl waiting for Vilém to come to her. However, Jarmila is soon informed that Vilém has been captured and sentenced to death for murdering the man who had previously raped Jarmila; unknowingly, Vilém commits patricide, killing his own father.

The narrative is moralistic and at times didactic. In keeping the spirit of nationalism, Vilém whose action in killing his father can be seen as a sin against the nation, must be sentenced to death and killed. Much like the moon who dawdled during the transition from day to night, Vilém has disrupted the cycle, though in a much more vicious way; his death will come after a long, seemingly never-ending night.

Vilém begins the start of a long, painful night. He experiences pain and extreme sorrow, finally coming to a trance-like state that dulls the pain:

The voice [from afar that the prisoner hears], the prisoner, both faint. 
And lightly the wavelets play

Beneath the tower o'er the lake's expanse,

And with them the breezes whisper,

Seeming to lull to sleep the prisoner,

Who lies there deep in swooning. (Mácha, II.346-351)

Though not dead, Vilém is in such a trance that he is barely alive; he dreams awake, murmuring unknown thoughts throughout the night, waiting for the bell to signal the procession to his death. Vilém is left to his thoughts, and begins to express them to himself, barely conscious.

No one, except the warder, hears Vilém's murmurings, and his utterances are such that the warder never repeats them, severely affected by what he heard, "...Yet his pale cheeks forever white / Never gave the world another smile" (Mácha, II.404-405). The reader is forced to decide what the prisoner says; Mácha has chosen to leave it open, perhaps so that the reader can fill in the blanks with his own ominous thoughts, thoughts so bad that they could cause one to never smile again. The fact that Vilém's utterance is not revealed offers the reader an opportunity to purge his negative thoughts in a way that is not harmful to the citizens of the nation. One is able to do so privately, and in ridding himself of such thoughts, he is able to move past them. It is important to a nation that is rebuilding its status for its citizens to resolve their worries on their own; the public revelation of frustrations and grievances with the nation can be selfish and poisonous to a 
nation that is beginning a new stage in its life. Mácha, with such imagery, creates a frightening path for his readers to follow.

The Narrator leads the reader on this journey to the past, sharing the story of the ill-fated lovers. Nature also plays a significant role; Nature is a parent to Vilém. Nature is a mother to Vilém; she comforts him on his final night and stays with him as he falls into a sleepless trance. Come midnight, Nature begins the preparations for Vilém's deathbed, similar to a mother who prepares her child's bed. The landscape awakens, and from it come different spirits, all with tasks to complete in the preparation for Vilém's death, as commanded by Nature. The skull of the previous tenant of what is to be Vilém's grave is still present, a reminder of what will happen when one sins against Nature. It is a didactic figure; eventually, Vilém's skull will replace the current one, and it is the spirits' job to remove the skull, a virtual changing of the guards, "Step out from the land of death, / Take on life - receive a voice, / Be amongst us - welcome here. / Long you had to dwell alone, / Now another takes your place" (Mácha, Intermezzo I.445449). The incantation reveals that the spirits themselves once inhabited this land, and that their skulls too hung above the burial site. The passage of time shows that the position is passed on one person at a time, and almost as an added punishment to death, the executed person must spend a predetermined time alone, marking his own grave, before he is able to join the other spirits and possibly move on to another world. Standing guard in this manner is neither penance nor restitution; as the leaving guard soon realizes, he is to live forever as a bodiless spirit. He must remain with the spirits and perform whatever duty is prescribed to him. 
The spirits are not the only facets of Nature that are to take part in Vilém's burial ritual. Everything, from the scaffold and wheel on the burial site to the falling dew and the moon must bring something to the burial. Time also has an important role in this ritual; Time must “...cover it [the grave] with a tomb” (Mácha, Intermezzo I.480). The passage shows that Nature is in control of everything; because Vilém has sinned against Nature and violated the natural order of things, he is destined to the burial and afterlife prescribed to him.

One is led to assume up to this point that the prisoner is being held in a remote area, with no one near but Nature and the warden to lament Vilém's damnation. On the morning of the execution, it is revealed that this is not true; Vilém has in fact been held in a town, and upon hearing the sound of the bell, they all follow in a procession to see the damned pay for his crime. Vilém walks alone to his death, but the crowd watches over him as Nature did before. They are not a loud, unforgiving crowd; the crowd's presence provides a sort of solidarity for the criminal at this time. The crowd comes into play because it is time for Nature to become silent, watching the ceremony: and waiting to begin her part of the ceremony "Past goes the throng - a black cloud in the sky, / From it - like lightning - the weapons gleam in the sun. / Slowly goes the wretch - gaze fixed on the ground. / From the town a bell's voice. The multitude pray for him" (Mácha, III.538541). The crowd forgives him, praying for his soul, although, as the Narrator has already shown us, his soul now belongs to Nature and is predisposed to whatever end she has decided for it.

The procession finally reaches its stopping point, at the height of a summit, and Nature once again becomes active. The sun shines brighter, alerting all to what is going 
on. Nature shines in all her splendid glory; it is a beautiful day. The fact that the day is so beautiful is painful, like adding insult to injury for Vilém:

All this the criminal sees again,

All that he has now to leave,

And deep grief seizes his heart;

he deeply sighs - tear follows tear -

Once more - a last time - all he surveys,

And turns heavenward his tearful gaze.

Across the blue azure the white mists die,

With them the gentle breezes play;

And high above - in the vast sky

White cloudlets float to far-off lands,

To them the grieving prisoner speaks:

"You, who in your far-reaching course

Embrace the earth as with a mysterious arm...

You out of all I have chosen as messengers.

Wherever you float in your great course,

Where you find your destination's shore, 
There on your journey greet the earth.

Ah, fair earth, beloved earth,

My cradle and my grave, my mother,

My only homeland for inheritance given

This wide earth, this single earth! -

And when on your course you see the cliff

Where on the lake shore - weeping a maid - ["]

He fell into silence, tear pursuing tear. (Mácha, III.596-608, 612-622)

In the passage above, Vilém has reached the full realization of the consequences of his actions. He cannot fathom that Nature can be so beautiful on the day of his execution, a day that is, in the figurative sense, ugly. However, she has come to the point where she must let go of Vilém; she cannot ignore her tasks, and must continue with the day as is planned. Though Vilém has killed another one of Nature's creations, she has always been his home and he will return to her in his death. Finally, his thoughts turn to Jarmila, alone and in mourning. First, he wishes that Nature will let her know that his fate has become a reality, but he is unable to finish the thought.

Vilém has come to the realization that news of his death might kill her, which, in fact, it does and he cannot bear to think that he will be the cause of her death, especially when he murdered his own father for violating her honor. Essentially, with the thoughts that he has lost Jarmila and caused her death, Vilém dies alone, and will remain so, a 
prisoner of Nature for a long time to come. In fact, Jarmila is already dead by the time Vilém is executed. She jumped off the cliff where she waited for Vilém upon hearing of his pending execution:

Quiet are the waves, the dark waters' lap,

All is covered with an azure cloak;

Above the water gleams the white dress's shade,

The countryside around whispers: "Jarmila!"

In the depths of the water: "Jarmila!"

It is late eve - the first of May -

Evening May - it is love's hour.

The turtle-dove calls to love's sports:

“Jarmila! Jarmila!! Jarmila!!!”. (Mácha I.135-143)

The above passage shows that Jarmila killed herself. The earth and the lake are calling to her, enticing her to make a home with them. The turtle-doves, known as a symbol of love, cry for her mournfully. Jarmila's death shows that her desire to live in happiness and love with Vilém is so great that she cannot possibly fathom life without him. She makes no attempt to see him before his execution or vouch for him and hopefully stop or at least delay his impending death; she answers the call of the ocean and ends her life. 
Jarmila's rape, though given little attention, is important to the text. Often times in literature, the feminine is valuable in its violation. It is unclear how the government would have handled Jarmila's rape, but because Vilém takes things into his own hands and commits patricide, he is sentenced to death. His sentencing comes as a result of his refusal to let the strong trample on the weak. Some might argue that Vilém's vengeance is punishment enough for Jarmila's rapist; however, one must wonder why a nation that was in the process of rebuilding would not have worked harder to prosecute and eliminate the rapist themselves, as they did Vilém. Others may call to question why exactly Vilém chose to take matters into his own hands; his rash action shows little faith for the government that the new Czech nation was attempting to establish. It is unknown how much time passed between the rape and Vilém's vengeful actions, though one is led to believe he acted quickly by the lines "...that he in slaying / Your seducer his own father slew. / Vengeance follows fast the deed. - / He dies in shame" (Mácha I.119-122). One is also led to believe that Vilém was caught quickly as well, as Jarmila sits waiting for him, unaware of what has transpired and ignorant of her impending death. Many things can be said about the tragic end to Vilém and Jarmila's love story, but if one were to read Máj as a political allegory, one can find the underlying significance of the poem. Vilém can be seen as the revolutionary fighting for his nation or Jarmila. Jarmila is representative of the Czech nation that was stolen of its identity by the Austrians, or Vilém's father. The murder Vilém commits becomes necessary in this view. A new republic cannot rise if the old, oppressive government remains. Finally, the pilgrim visiting the pilgrimage site is the new citizen who must recognize what has occurred in the past in order to move forward. 
In literature, rape often brings the formation of a republic; many poems, such as William Shakespeare's The Rape of Lucrece use this equation. Similarly, Máj introduces such a concept. Jarmila's rape can signify the necessity for a political change. Like the old Czech nation, Jarmila was overtaken by a larger, stronger force, and as a result was damaged for life. Jarmila, or the old country, ultimately must die so that the new country, represented by the pilgrim can flourish. The closing call of Máj, "The turtle-dove's voice calls to love: 'Hynek! - Vilém!! - Jarmila! !!'” (Mácha IV.823-824), can represent the connectedness of the characters. It is up to the reader to decide if it is hopeful or ominous; similar to lines in Childe Harold's Pilgrimage, such as, "Our coming evils with a crutch-like rod, / Whose touch turns Hope to dust, - the dust we have all trod," (Byron IV.125.1124-1125), this incantation can be read as a warning that things may be difficult along the way. While love is an important part of the narrative poem, the focus of Máj is not solely on the love story; it is on much more than the story of two star-crossed lovers.

Bronislava Volek argues that the focus of the poem is not the love that Jarmila and Vilém have for each other; instead, the focus of the narrative is the longing that they feel for one another, "Love is associated with death, and interpreted as longing. One can die of longing, one does not die of love" (349). Volek's assertion that Máj is a story of unfulfilled longing, rather than forlorn and ill-fated love, emphasizes the fact that, in reality, the importance of Mácha's narrative poem is not about Jarmila and Vilém's love for each other. Instead, it is about remaining true to one's longings. As mentioned earlier, if one's longing is self-centered, it can be dangerous. In murdering Jarmila's offender, Vilém killed his own father, and sealed his own fate, destroying the chance of ever being with his beloved Jarmila again; he did so rashly and without consideration, not 
thinking of Jarmila's feelings. Because the story is being told in hindsight, we are left unaware of Vilém's motives. Obviously, he intends to avenge the horrific act; however, it is unclear if his desire for vengeance is to protect Jarmila from further harm, or to satisfy his need to be the aggressor. The underlying nationalistic didacticism of this tale is that one must refrain from selfish acts, as they can be detrimental to the ideal that one is trying to aspire to.

The narrative shifts from our departed Vilém and Jarmila, and the Narrator comes to life. The Narrator and the pilgrim are one, we realize; though the pilgrim has been silent in the narrative until now, we hear his story. He has gone on this journey, approximately seven years after Vilém's death, and has come to his resting place, staying at an inn near the gravesite. He and his horse experienced a great fright upon seeing the shiny lonesome skull, and approached the innkeeper about it, who told him the story that he (as the Narrator) has just recounted. Vilém and Jarmila's story has remained with the pilgrim, and he is not wholly satisfied with his journey.

In order to satiate his desire to fully experience Jarmila and Vilém's tragic tale, the pilgrim decides to return on the anniversary of the occurrence:

And round the skull the sunset glow

Laid itself like a garland of roses;

Colouring the bony, white cheek

With its hanging skin beneath the chin...

Here and there a long hair flew, 
Left to the white skull by time,

And dew drops blushed there beneath,

As if the skull's hollow eyes,

Moved by May's evening beauty

Glittered there with mournful tears. (Mácha IV.769-772, 775-780)

Vilém's skull still hangs, now approximately eight years after his death, and Nature remains watching him, bathing him in light and making him look almost messianic, although the light that frames the skull will soon fade, a reminder of Nature's ability to make things both holy and unholy. Jarmila's soul is not physically there with Vilém, although a lock of hair floats by him, reminding him of her existence, and reminding the reader that though they were separated by death and never to reunite, Jarmila and Vilém's love for each other remains.

The final chapter of Jarmila and Vilém's story emotionally affects the pilgrim, bringing his humanity to life. One senses that there is a reason the pilgrim has come to this site, and he is beginning to realize that himself. There is more, our narrator realizes, to the story than just the ill-fated love between two young people. It is a reality for the reader as well; being as the Narrator is unreliable in repeating a story that he has heard from someone else, it is up to the reader to the realize that the importance of the poem as a whole comes from the pilgrim/Narrator's experience and his reaction to it. The narrative is about dreams left unfulfilled and incomplete, and the pain that can come from such dreams remaining unsatisfied. Ultimately, had Vilém not acted out of his jealousy 
and killed his own father, he would have been able to return to Jarmila, and they would have lived together in the happiness of a lover's dream fulfilled. Eventually, they would have died, and been reunited in paradise, allowed to live in communal love for eternity. However, because Vilém sinned, though out of love, the chance of living in eternal love was diminished; Vilém is left with dream of seeing his love again, and with her hair as a reminder of his love for her.

Reflecting on this, our pilgrim realizes that this is what can happen if the dream of creating a united Czech nation were lost; he also realizes the danger of acting rashly and without thought. If those who were fighting so hard to gain a Czech identity acted indecently and improperly, the consequences would be great enough to eradicate the possibility of a Czech paradise. If the patriots lost hope and forgot their dreams, the pilgrim realizes, the aftereffects could be just as bad:

Far away is its dream, dead as a shadow's shade,

As [the] white towns' images sunk in the lake's lap,

As the last thought of the dead,

As their names, the noise of ancient battles,

Age-old northern lights, their extinguished glow,

Wrecked harp's note, torn string's tone,

Vanishes age's action, dead star's gleam,

Perished comet's track, dead beloved's feeling, 
Extinguished fire's smoke, molten bell's voice,

Dead swan's song, man’s lost paradise. (Mácha, IV.799-809)

The pilgrim uses the image of immediate and unexpected ending to describe what happens when the dream is lost. Everything he mentions in the passage above comes to a sudden and abrupt stop. Should the patriots lose their hope and dream in creating a nation that was to be respected and glorified, all progress would stop. Had Jarmila and Vilém stopped loving each other, then the spring would not have come again; the wheel of Time would have stopped because of the interrupted dream.

The pilgrim, becoming aware of the message involved in the story of Jarmila and Vilém realizes that his journey must continue, he must move forward from this place and not look back, but recall the memory of this voyage. He moves on from the site, knowing how he must lead his life from this point on:

Do you see the pilgrim, who, down the long meadow,

Hastens toward his goal before the sunset dies?

Never again shall your eyes see this pilgrim,

As he passes behind that rock on the horizon,

Never - ah never! That is my life to come.

Who shall give such a heart what comfort?

Love is without end! - My love's deceived! (Mácha, IV.814-820) 
The above stanza shows that the pilgrim must move on, and while he continues to move forward, he must remember that love is eternal, therefore he should act in love; he must work to ensure its eternity. The pilgrim came to the site, and upon his first learning of Jarmila and Vilém, he felt that love was short lived and terminal; this second voyage to see Vilém's skull has made him realize that he was mistaken; although Jarmila and Vilém's love was left unfulfilled, the dream that they could be satisfied in their longing for each other's love remains and will remain forever.

The pilgrim has found the answer to the invocation offered at the beginning of the narrative. In order for the Czech people to rise again, they must promote their love for their country, for its land, for its language. The dream of a Czech Eden could be realized with the pride and love felt by the Czech citizens. One is led to infer that these sentiments were felt by the author himself. Karel Hynek Mácha references himself in the final lines of the poem; he is united with Jarmila and Vilém, "It is late eve - the first in May - / Eve in May - it is love's hour; / The turtle-dove's voice calls to love: / 'Hynek! Vilém!! - Jarmila!!!"' (Mácha, IV.821-824). The turtle-dove calls to the lovers, this time including Hynek, whose love for his country transmuted into the love story of Jarmila and Vilém; a love story that is meant to inspire and entice the people, his audience, to rise above and act on their own, becoming independent from the example of the nobility, and succeed on their own. The creation of an outstanding Czech nation this time depended on the people, on their pride and love for their country and heritage, and a willingness to act independently for the benefit of the nation.

Karel Hynek Mácha brings two heroes into his narrative poem. Vilém, though a bandit and a murderer, is heroic in his willingness to commit such a heinous act in order 
to defend and protect his love. Ultimately, he is saddened by the pain he has caused Jarmila, and that is what causes him the most pain. Still, he realizes his death has become even more necessary. Vilém must die for what he did, not only because he broke the law, but also because Jarmila's pain and death will have been in vain should his life be saved, giving even more reason to the fact that Vilém is resigned to his death.

The second hero is the pilgrim. Though nameless and faceless, this is his narrative; he has filled the role of both pilgrim and Narrator because he must take the readers with him on his journey and he must ensure that they become aware of the didacticism involved in the story of Jarmila and Vilém. As the pilgrim, it is his role to return to the pilgrimage site until he fully understands the implications of what he has seen and heard. Upon his first visit, he does not gather that the love between Jarmila and Vilém is representative of the love that the Czech citizens must feel for their nation in order to fulfill their longings in becoming a nation that is to be remembered with proud eyes.

It is not until the pilgrim returns, upon the anniversary of Vilém's death and sees the skull and the lock of hair that he realizes that this love has lasted and will continue to last. As already stated, one assumes that upon the death of two lovers their souls will be reunited in the afterlife and that their love will be eternal. Jarmila and Vilém's love for each other is eternal, although their souls have not reunited. Because of his transgression, Vilém severed the chance of the unification of their souls. However, because Jarmila and Vilém both died in love with each other and dreaming that their love for each other will overcome even death, part of Jarmila is left behind, allowing Vilém's soul, hung above the gravesite, to continue to love her. 
The pilgrim realizes how one's love for one's country should be: constant and unwavering. Having journeyed on his own, the pilgrim is unattached and independent. He is not tied to the longings of Jarmila and Vilém; his longings have to do more with the desire to see his nation rise out of the ashes again, to loose itself from the binding ties of a massive empire, and to exist independently and successfully. The pilgrim's hope is to see the Czech nation become a better version of the powerful nation that it once was. $\mathrm{He}$ hopes to see the glory of the Czech lands recognized by those within and without the nation. He wants the people to be proud of their nation, embrace its language and its culture, and act progressively in the fulfillment of these dreams. The pilgrim's longings reflect those of the poet; because of his sudden death, he was unable to do more for the development of the nation, but in Máj he left the framework under which the people should work to promote patriotism and national identity. In Máj Karel Hynek Mácha ensures that he promotes the National Revivalist ideal while enveloping it in the trappings of Romantic poetry. 
When looking at Byron's Childe Harold's Pilgrimage and Karel Hynek Mácha's Máj together, one soon realizes that the similarities between these two works of narrative poetry are important in showing that the Romantic Age was able to bridge countries, and manifest itself differently. The construction of heroes and heroism involved in Romantic literature plays a significant role in the romanticism of both the United Kingdom and the Czech lands. As has already been discussed, the heroes in Childe Harold's Pilgrimage and Máj are a departure from earlier figures of heroism, and this difference resulted in a refreshed and renewed literature in which the people's participation became a necessity.

Milada Součková writes in The Romantic Wasteland that Mácha undertook a huge task in deciding to incorporate Romantic, especially Byronic, tendencies into his poetry, as "The Czechs condemned the 'Byronic' trend as detrimental to the healthy development of the nation" (39). It is true that Byronic ideals, especially those found in Childe Harold's Pilgrimage of abandoning one's country and station for one's personal development, could cause readers to turn away from the nation, especially a fragile nation like the Czech region. Mácha understands this, though he also understands the potential that Lord Byron's narrative, if tweaked, could have, especially for a people looking for a new kind of hero. Ultimately, differences and changes in Byron's technical work serve to promote the purpose Mácha felt his poem should cater to. Keeping the theme of a travel narrative, as well as a dependence on Nature and the Narrator, however, allows Mácha to use Byronic imagery that fits the Czech ideal. Mácha's use of Byronic techniques shows that Byron's significance as a poet comes from the malleability of his work; though in 
writing Childe Harold's Pilgrimage Byron had his own purpose, he leaves it open for other poets and even readers to mold his poetic functions to fit their own designs.

The purpose that the poets were trying to fulfill in writing these poems highlights the importance of their similarities. Childe Harold's Pilgrimage served to create a hero that would be modified and varied for time to come. Máj served to take Byron's hero further; Mácha's hero could not simply be a Czech copy of an English hero. Czech Romanticism had to please two very different groups- first and foremost, the Czechs, and second, the Western world. Czech Romanticism then is a sort of hybrid, fusing together the nationalistic sensitivities of the Czechs with the severe individualism of the Romantic Age. Combining nationalism and individualism was not enough for Mácha, however, who more Romantic than nationalistic himself, felt the need to consider a third facet in his writing.

The new feature that both Byron and Mácha employed was discovering the poet himself; that is, discovering what it meant to be a poet, and how a poet should live. In including themselves in their poetry, and, specifically, in Childe Harold's Pilgrimage and Máj, Lord Byron and Mácha began toying around with blueprints for what they felt was the ideal poet. The sketches they draw in their narratives show an overt participation in the narrative itself, rather than solely in the creation of it.

The new participatory role of the poet helped to round out these narratives and make them more fully developed. In his introduction to Eastern and Central Europe, James Naughton writes, "Writers were looked upon as 'the conscience of the nation', as 'teachers of the nation'; they found themselves expected to cultivate national mythologies and bolster self-esteem" (x). The view of writers that Naughton introduces fits the roles 
of Romanticism in both the United Kingdom and the Czech region. If the Romantic poets expected their readers to participate actively in the literature and culture of their time, then the poets had to create a trustworthy character that the people could relate to. Often times, the poets decided to add traces of themselves in their poetry, bringing their heroes on paper to life. Though Byron was known to repeatedly deny allegations that the character of Childe Harold was based on his own life, one can still draw conclusions about the poet writing himself into the poem. Jerome J. McGann writes, in his introduction to Lord Byron: The Major Works:

Byron writes himself into all his poetry, of course, but the self thus represented is always viewed in a detailed context of impinging social and historical relations... This quality of his work is reflected in all its material aspects...in the range of the styles which he not only used, but also took seriously - from the most ephemeral types of street songs, ballads, and vers de société to the heroic manner of the tales, the high rhetoric of the satires, and the noble numbers of poems like Childe Harold's Pilgirmage.

In the case of Childe Harold's Pilgrimage, it can be argued that Byron develops himself in the characters of Childe Harold and the Narrator. I have already posited that the pilgrim is an early version of the Byronic hero, and that the Narrator can be seen as the fully developed version; likewise, the pilgrim can reveal the musings of a young Byron, and the Narrator can be seen as the older Byron. Looking at Child Harold's Pilgrimage in these terms, one questions what it is that Lord Byron was struggling with and hoped to conquer. Lord Byron's personal history is an interesting one. His mother was of noble 
blood, and he assumed the title of Lord when he was ten years old, after his great uncle passed away. Byron began attending Parliament under the House of Lords after his twenty-first birthday, though he soon left England and began traveling through Greece and Turkey. From his writings, one can assume that Lord Byron became increasingly frustrated by the constraints that his noble heritage and participation in Parliament imposed upon his desire to live a life free of rules and decorum.

Traces of this internal struggle that Lord Byron endured can be seen in Childe Harold's Pilgrimage. The pilgrim, in representing the young Lord Byron, is, according to Byron, "...very unknightly, as the times of Knights were times of love, honour, and so forth. Now it so happens that the good old times, when 'l'amour du bon vieux tems, l'ámour antique' flourished, were the most profligate of all possible centuries" (Addition to the Preface 19). Describing Childe Harold as the antithesis of a knight when the times prescribed knightliness reflects Lord Byron's own abandonment of social and political decorum. Being a person of rank in society, it was one's duty to comply with that which his title required of him; in Lord Byron's case, this was attending Parliament and participating in the House of Lords. However, this was difficult to manage for a man whose desire was to express his thoughts freely, and in the form of poetry, which was generally considered with dubiousness.

The final canto of Childe Harold's Pilgrimage was written in 1817, with Lord Byron again in exile from England, resulting from the combined scandals of alleged incest and abuse. The Narrator in Childe Harold's Pilgrimage reflects a wiser, more mature, pilgrim, like Lord Byron on a second journey. The Narrator has been tempered by his first experience and is willing to act as guide and confidante for the younger, 
guileless Childe Harold; once Childe Harold disappears, the Narrator comes into focus, reminiscing with the audience. The Narrator approaches the sea with the highest regard, eternally connected to her:

$$
\begin{aligned}
& \text { And I have loved thee, Ocean! and my joy } \\
& \text { Of youthful sports was on thy breast to be } \\
& \text { Borne, like thy bubbles onward: from a boy } \\
& \text { I wantoned with thy breakers - they to me } \\
& \text { Were a delight; and if the freshening sea } \\
& \text { Made them a terror - 'twas a pleasing fear, } \\
& \text { For I was as it were a child of thee, } \\
& \text { And trusted to thy billows far and near, }
\end{aligned}
$$$$
\text { And laid my hand upon thy mane - as I do here. (Byron Childe Harold's }
$$$$
\text { Pilgrimage IV.184) }
$$

The Narrator's appreciation for the sea is great, and one can tell that, just as Lord Byron did, the Narrator has embraced a new home and a new identity. The Narrator is a child of the sea; Lord Byron returned to his beloved Greece and died there. Essentially, Byron had to leave his prior life in order to be able to live life as he pleased. The restlessness of the young poet seen in Childe Harold gives way to the calm nature of the Narrator, an older Lord Byron who made the decision to lead his life as he pleased and forgo the rigid parameters of English society. In making such a decision, Lord Byron has made himself the example for his readers to follow; because of him, those reading Childe Harold's Pilgrimage can have the courage to make a decision that will affect their lives, and taking care to see their plan through, affect it in a positive way. 
Like Lord Byron, Karel Hynek Mácha chooses to incorporate himself into his poetry; however, he does so much more overtly than his British counterpart. The opening of the poem is an incantation to the Czech people, imploring them to retain faith in their country, and act in such a manner as to reflect what the Czechs have to offer as a nation. The desires outlined in the incantation show the desire of a poet who worked to increase pride in his country, and promote the ideal of nationalism. He exclaims that

The Czechs are a faithful people,

Faithfulness is their first honour;

To their country and their king

The Czech is faithful even in death.

My God - my king - my country!

Is the last sigh of a Czech

The Czechs are a faithful people

And you are their son - a faithful Czech! (Mácha, 21-28).

The above passage reflects the revolutionary ideal of a people who are faithful to their country and home, an asset necessary in the development of the Czech nation. The description of such faithful citizens can be seen as the dream of the poet, and this is not the only trace of his identity in the poem; in the final stanza of Máj, Mácha reminds his reader of his existence, and his attachment to the poem. The poem closes with the turtledove's cry of "Hynek! - Vilém!! - Jarmilla!!!" (Mácha, IV.824). The final call of the poem functions as an affirmation of the author's participation in the narrative. As already discussed, the pilgrim and the Narrator in Máj are one and the same; Mácha ensures that 
he reveals he is the one who has taken his readers on this journey. Mácha has fulfilled the duty of becoming the person to which his readers can relate as they read Máj.

Milada Součková argues that this final revelation that pilgrim, narrator and poet are the same is significant because it gives a physical presence to the traveler. He is made real, she says, because

Hynek, who lingers by the gallows until the moon rises and makes the skull's cheeks and his own paler, is the Romantic Wanderer, whose youthful dreams have been shattered and whose heart has been burnt into cinders of despair. Once Vilém's skull carried images and thoughts which were Hynek's too; they had the beauty of youth, its raptures, its disillusionment, and theirs was the agonizing idea of 'nothingness'. (Součková 77)

Součková's thoughts show that Hynek, as a poet, successfully appeals to his reader in creating a character that reflects his unsettled mind. Vilém's death has a profound effect on the pilgrim/narrator/poet, because, in essence, the poet's dreams have died with him. Initially, he does not see the promise that death brings in the narrative, but upon his second visit, he recognizes that the deaths were necessary and that the future of his country lies in his hands. Before the turtle-doves issue the final call to the departed, including Mácha, the pilgrim exclaims that he can never come back. The full story has been completed, and as such he must walk away and move to the next phase: "Do you see the pilgrim, who, down the long meadow, / Hastens toward his goal, before the sunset dies? / Never again shall your eyes see this pilgrim, / As he passes behind that rock on the horizon, / Never - ah never!" (Mácha, IV.814-818). The pilgrim hastens toward his new 
goal, saddened to leave Vilém and Jarmila, but recognizing that he must press on. The poet must move on as well; he cannot dwell on this story of longing, for if one lingers too long on their longings, they run the risk of being stuck for eternity and with little hope as Vilém's skull is hanging on that spot for an unknown amount of time.

In incorporating themselves into their poems through the use of the Narrator, Byron and Karel Hynek Mácha make the Narrator one of the most important characters in their narratives. Only one character has equal importance: Nature. In Máj, the construction of Nature is very similar to that of Nature in Lord Byron's Childe Harold's Pilgrimage. The pilgrims in both poems make a return to Nature. They have lived in the city and in order to grow, they must come back to Nature. Life in the city is a life of rules and structure; Nature is cut up into plots of grass and trees that have been strategically planted for their aesthetic value. The reconstruction of Nature in Childe Harold's Pilgrimage and Máj as wild is the opposite of human life; Nature is wild so that the poets and pilgrims can break free of the constraints imposed on them by society.

The wildness of Nature is what attracts the Romantic poet. He feels Nature, experiences life through Nature; Mácha's poet also experiences life through Nature, but does so in his own natural environment, that is, in the Czech lands. While most of the Romantic poets use travel to motivate the action in his poetry, Mácha's poet, like William Wordsworth, brings the Nature already surrounding him to life, thereby creating a stronger bond between the poet and Nature. Mácha's poet is constantly thinking of Nature, creating a mother and son relationship, giving himself over body and soul to Nature, or as James Naughton suggests, participates in “...the ascribing of human emotions to nature" (57). The Romantic poet struggles with Nature's role in terms of 
emotion; often Nature is the cause of both joy and sorrow, as easily given as taken away. He struggles with the fact that Nature has the rule, and he does not have the choice or ability to feel as he thinks he should. In both poems, Nature keeps her literal role; for instance, in both cases, changes in weather signify important occurrences in the narratives. The pilgrims have no choice in these matters; ultimately, Nature remains the mother with the ruling hand. Mácha's pilgrim gives up the ability to choose his own fate, allowing Nature to do what she intends; he remains passive and does not fight the battle he knows he cannot win. In so doing, he creates a relationship with Nature in which Nature becomes very much the nurturer.

The Romantic poet's Nature is also nurturing and forgiving. As we see in the following passage from Childe Harold's Pilgrimage Nature remains kind to the poet:

Dear Nature is the kindest mother still,

Though always changing, in her aspect mild;

From her bare bosom let me take my fill,

Her never-wean'd, though not her favour'd child.

Oh! She is fairest in her features wild,

Where nothing polish'd dares pollute her path:

To me by day or night she ever smil'd,

Though I have marked her when none other hath, And sought her more and more, and lov'd her best in wrath. (Byron, II: 37. 325-33)

In the above lines, the poet shows his complex relationship with Nature; more than just a give and take relationship, it resembles the relationship between mother and her child. 
The poet worships Nature, calling her the "kindest mother" and "mild", and relates that he is not "her favour'd child" and has "lov'd her best in wrath". Nature remains kind to him, though he has acted like a child, ungrateful for her nurturing grace. The lost boy continues to seek her, much as a sinner continues to seek religion for forgiveness and fulfillment. The passage also shows the poet's recognition that Nature is in control and that no matter how many times he acts against her, he will never be rid of her.

The solitude that Nature provides also attracts the poets and makes them want to participate in this voyage. For the heroes, will is a necessity. The hero must be willing to face his own despair and do so alone. While in reality, the pilgrims' solitude is an effect of the poetry, Byron and Mácha both emphasize that their pilgrims face their foes alone. The self-imposed solitariness shows how willing the pilgrims are to go on this journey. Byron emphasizes the connectedness of Nature and solitude in the following lines:

To sit on rocks, to muse o'er flood and fell,

To slowly trace the forest's shady scene,

Where things that own not man's dominion dwell,

And mortal foot hath ne'er or rarely been;

To climb the trackless mountain all unseen,

With the wild flock that never needs a fold;

Alone o'er steeps and foaming falls to lean;

This is not solitude; 'tis but to hold

Converse with Nature's charms, and view her stores unroll'd. (Childe Harold's Pilgrimage II.25) 
In the preceding lines, Byron shows that it is when one faces Nature alone that one can truly experience Nature. When one is alone with Nature, one can listen to what she is saying and grow from what she is saying.

In the above passage, Byron shows that solitude is necessary for growth, and Mácha echoes this solitude in $M a ́ j$. Vilém faces his final night alone; his only visitor is the warden who comes to his side when he hears him shriek in pain. He does not ask for visitors. There is no part of the poem where Vilém wonders why he is alone. Rather, he is willing to spend his final night in solitude. The pilgrim also journeys to the site of Vilém's grave alone, and he does not bring anyone with him the second time he visits. He is willing to bear witness to Vilém on his own. The fact that Mácha constructs a pilgrim who is willing to participate fully in whatever is required of them is important, as willingness is one of the most important factors to a burgeoning republic. Solitude is necessary for the citizens of a growing republic who need to revisit their history and become reacquainted and reconnected with Nature.

René Wellek examines the connection between these two poets and Nature. Nature for the Romantics was one of the most important realms to analyze. It is important to note that one of the most interesting facets of Nature is that there is no concrete way to look at it. Its subjectiveness is, as Wellek shows, what drew many of the Romantics to it: "Mácha wavered between two familiar conceptions; at the one time Nature seems to him a sympathizing comrade of Man, at other times she seems completely different to human sorrow. This very same dualism can be found in Byron; the contrast between the human heart and Nature is one of the main topics of Childe Harold..." (Mácha and Byron 411). As Wellek points out, passages such as those above 
show the dualism that the Romantic poets demonstrated so well. Dualism emphasizes the subjective nature of both poems; only internally can one recognize the duality of Nature. It also strengthens the belief that Nature could create a spiritual world. In this world, one was able to escape that which he wished to escape. As much as Nature served to provide an escape for the weary, it was also a place in which one could wander freely in hopes of bettering himself. For the Romantic poets, Nature held such a high position, she was almost a saintly figure.

Wellek argues that although Mácha's view of Nature is similar to that of Lord Byron's, and he also claims that there is one essential difference in their views:

Byron, in any case, never ceased believing that Nature has a spiritual meaning, and usually in Mácha the same feeling of a symbolic expression in her features prevails, whether it is in harmony or in conflict with the mood of Man...Though Mácha did not desert the romantic view of the symbolic meaning of Nature, his conception of Nature is considerably different from Byron's. Nature in Mácha is completely dematerialised, a mere whirl of colour, light and sounds, a stream carried away by inexorable time - a conception which could make us think of impressionist painting. (Mácha and Byron 411)

Wellek's assertion is true to an extent; Nature is described a cloudy and blurry throughout the whole narrative, though her presence can be felt throughout the narrative. Also, Nature's role in burying Vilém reflects her importance. Burying a person is the last act one performs before the deceased is able to transition to a new life. Though Vilém eliminated his chances of moving on to a world of paradise, at the same time, he ensured 
that his relationship with Nature would never end. He was now under the care of Nature, for eternity. It is Nature's job, as the warden, to prepare Vilém's resting place. It is also important to note that the physical topography of the Czech lands is working to bury Vilém as well, "The mist over the hills / 'I shall add the white shroud.' / Night / 'I shall bring black robes.' / The hills about the landscape / 'Give to us these robes and veils.' / The falling dew / 'And I shall lend you tears"” (Mácha, Intermezzo I.467-474). This heightens the nationalistic tone of the poem. On the one hand, Wellek's assertion that Nature in Mácha is fragmented is true; however, the moment in which they converge is one of the most important moments of the narrative, which shows that Mácha has created a physical role for Nature. Although the separate parts of Nature each have their specific role, they are working together in order to bury Vilém.

Nature cannot, and will not, desert the pilgrims for their transgressions. As in Childe Harold's Pilgrimage, Nature is disrupted in Mácha's Máj; however, the poet in this case is not the offender, rather he is recounting the story of sins committed. The sin in this case is succumbing to one's passions, as Vilém, Mácha's hero, did. In this case, the poet sees Nature sin and pay for her sins as the characters of this poem do. The following passage reflects the sin and repentance experienced by Nature:

The full moon's face so beautiful -

So palely bright so brightly pale,

Like lover seeking her beloved-

Flamed into a rosy glow;

Her watery images she espied;

And there for love of self she died" (Mácha I.20-25). 
Nature, in this case is the Moon, who experiences the same passion the lovers are experiencing, though once the height of passion is reached, she must repent, because she acts in selfish love, rather than selfless love. The worshipper's sin becomes the god's $\sin$, and therefore, the god must die. Nature does this willingly, however, fulfilling her role as nurturer and guide, and comes back to life. In both the case of Byron and Mácha, Nature fits the role of mother, of nurturer, and of guide. The difference lies in that Byron's poet learns from his faults, while Mácha's poet learns from the sins of others.

Equally important in examining the relationship between Byron and Mácha's poet is examining the nature or natural surroundings of each poem. The topography of both poems is significant because the poets are often influenced by their surroundings. Byron begins his tale in England, on land. His hero, Childe Harold is restless with the everyday and the constant, and therefore decides to take a trip spanning the Mediterranean and Aegean Seas; he follows Europe's political history. Life on the sea is fragmented; it stops and begins as the ship stops and continues on its journey. The physical action of the poem that takes place on the water is also fragmented. In his essay, Mácha and English Literature, René Wellek comments on this as a Byronic convention, saying "...Byron was the initiator of the genre of the romantic tale in verse, with deliberate fragmentariness and obscurity of action" (172). The fragmentariness allows for the reader to have a more active role, though as we will see, the fragmentariness also allows for the righteous sense of individuality that characterizes the Romantic age.

In Childe Harold's Pilgrimage, fragmentariness comes from the water; it follows the waves as they rush and break. The ocean is the setting for the major parts of the 
poem, and it is sailing on the ocean where the poet himself comes alive in the poem and where Childe Harold, his hero, disappears:

But where is he, the Pilgrim of my song,

The being who upheld it through the past?

Methinks he cometh late and tarries long.

He is no more - these breathings are his last;

His wanderings done, his visions ebbing fast,

And he himself as nothing: - if was

Aught but a phantasy, and could be class'd

With forms which live and suffer - let that pass -

His shadow fades away into Destruction's mass. (Byron Childe Harold's Pilgrimage IV: 164.1468-1476)

Like the ocean, the Pilgrim's perceptions of his great journey have ebbed, and so he disappears in the vast ocean that continues to ebb and flow. His life is suddenly fragmented, and with the abrupt end of his Pilgrim's journey, the poet's journey is also fragmented and stopped abruptly. Because the poet's time has also been cut short, he spends no more time lamenting the passing of his dear Pilgrim, rather, he continues to the end of the poem speaking of his own relations with nature and the ocean, thus making the poem about him in the end.

The fragmentation in Máj comes at the beginning. In the opening scenes of the narrative, water is present and commanding; the opening action happens at what is now known as "Mácha's Lake", near Prague. As with Childe Harold's Pilgrimage, the action that takes place at the lake is fragmented and obscure, and the lake brings finality to the 
poem as well. It is into the lake that Jarmila, Vilém's love, jumps upon hearing about his impending execution. With Jarmila's death, the lake is gone as well. The lake itself is large and fragmented, abruptly removed from the poem.

The rest of Máj takes place on land, in the Czech lands, near the town of Hiršberg. In this case, the poet is the pilgrim; he is journeying through the countryside. Nature is kind to its pilgrim, so kind that he comes back a second time, to see Vilém's skull as it should be seen. Of this visit, our poet says:

Again it was eve - the first in May -

Eve in May - it was love's hour;

The turtle dove's voice called to love,

Where the pine grove wafting lay.

Love whispered soft the quiet moss;

The blossoming tree lied love's woe,

The nightingale sang love to the rose,

The rose's shown by an odorous sigh.

Smooth the lake in shadow'd bushes

Darkly sounded secret pain,

The shore embraced it round and again,

Like brother and sister in childish sport. (Mácha IV.757-758)

The nature that the poet sees this time is calm and loving, it is restful. The lake is smooth, held by the brotherly shore. In the above passage, there is a constant play between nature and the animals that inhabit it, namely the birds. The birds are alive and thriving; they sing songs of love and joy, adding to the serene feeling. Nature here is not 
individualistic; the passage shows that each part of nature has an importance, appealing to the nationalistic sense of the Czechs at the time.

At the end of his poem, Mácha is both Byronic and "Máchean" at the same time. With Máj, Mácha achieves the fusing of Romanticism with the National Revivalism that was happening in his homeland. As Wellek points out, however, Mácha's efforts were not altogether appreciated by his contemporaries, "His poetry is alive today for its own sake, for its music, imagination and power of thought, which belies the common label of Byronism with which he used to be praised and then derided in turn" (148). The derision that Mácha's peers felt for him is interesting, because, as I have shown, Mácha was careful to incorporate his identity, and that of his people, into Máj, while at the same time writing in a style that was both popular and one he enjoyed. His decision to write in such a manner remains successful, as Wellek mentioned. Had he continued in the National Revivalist style of his contemporaries, he probably would have gotten lost in the sea of the other Czech writers.

Mácha seems to have realized the inherent difficulty in creating a new Czech tradition, especially one that was meant to thrive both in terms of the nation-state and in terms of becoming a powerful European culture again. Lass comments on this, saying, "The process of national identity and national history, the importance placed on 'folk tradition' and the roles assumed by the artistic and intellectual elites, as well as the 'objective' historical determinations that resulted in the transformation of AustroHungary into the independent nation-states of Central-Europe, are equal and interdependent facets of one cultural process" (456). In Máj, Mácha attempts to achieve this; his narrative is folk, mystical and outrageous at the same time. Though Mácha was 
not rewriting an old folk tale, his simple manner reminds the reader of a story, rather than a convoluted poem.

The simplicity of Mácha's poem also reflects the Czech manner of writing, more so than that of the Romantics. Byron's Childe Harold's Pilgrimage, by contrast, is much longer and convoluted. Byron ignores the possibility that his reader may not be familiar with the many places featured in Childe Harold's journey. Since the Czechs were recreating a culture both within themselves and Europe, it was necessary that Mácha write something readable by both layman and intellectual alike, allowing him to fabricate a story that is simple, yet infused with enough wonder and insight that one is not bored. The rebirth of Czech culture creates the need for Mácha to combine the two traditions as well. It would have not been successful for him to have written the entire poem purely in a National Revivalist manner, though he did add stanzas defining the Czechs as kind, stout and faithful, which are important in bringing Czech nationalism into the picture.

Though Mácha's nationalistic tone in Máj is a departure from Byron's individualistic tone in Childe Harold's Pilgrimage, it is significant that Mácha chose to present the national ideal in the form of a narrative. Rather than proselytize and deliver a sermon to his readers, he takes a cue from Lord Byron and draws them in with a story. One can argue that Mácha's incantation can read as a sermon; however it serves to rally the readers to his cause, and bring the national revival to light, and Mácha is sure to keep it short, and allow the story to take over. There is an advantage to using a narrative form to deliver a message, especially to a group of people who are weary of garrulous peptalks that do not have any effect. If one can cause a group of people to become enraptured in a tale, then one can efficiently relay his or her desired message to them. 
Lord Byron does this in Childe Harold's Pilgrimage. Byron's story of a rogue knight immediately interests his readers. Though Byron's narrative is extensive, he does not lose his reader's interest; the reader follows Lord Byron's narrative because of the fragmentariness that Wellek referred to. In having the knight move in and out of the narrative, Byron creates a wave-like movement. The narrative crashes and stops whenever Childe Harold comes back into the story, and the reader is now on the journey with the pilgrim; he leaves again, and the reader is moved by the flow of the ocean and the Narrator's tale. Byron's use of fragmentariness goes one step further with the fact that his cantos were published separately. Rather than wait to publish the whole narrative at one time, Byron kept his readers expectant as they awaited each subsequent canto, especially the third and fourth, which came quite a bit later than the second canto.

Similarly, Karel Hynek Mácha works with several stories in Máj. Once the incantation has ended, Jarmila is introduced, and her story begins. As quickly as her story begins, it ends, and moves to Vilém. This abrupt stop can come as a shock to Mácha's readers, but the fragmentariness of the tale keeps the readers awake and allows them to think critically about the significance of the story. The shift from Vilém to the pilgrim/narrator is smoother than the initial transition from Jarmila to Vilém, but it is still unexpected, especially when one realizes that the pilgrim is the narrator and is recounting a story that was told to him. The shift in character adds to the idea of brokenness and obscurity that Wellek was referring to in regard to Lord Byron's narrative style. He further posits that "Fragmentariness as such was for Byron one of the main stimuli of the imagination" (Wellek, Mácha and Byron 408). In following this model, Karel Hynek 
Mácha creates a narrative that jars the reader into recognizing that the narrative has to do with something bigger than the love story between Jarmila and Vilém.

The fragmentariness in both narratives works, as Wellek says, to stir the imagination. It not only works to stir the imagination of the poets, whose works show their invaluable imaginations. It also effectively stirs the imagination of the reader. The abrupt stops and starts of the narratives cause the readers to think critically about what they have read. The action that takes place in the poems is ultimately not important; the action is deemphasized. What is of most importance in these poems is the subjective journey. This is what the reader must seek and pay attention to. The allowance for thinking promotes the idea of the participatory audience, something that was considered and valued by both poets.

In closing, Mácha's position as a Romantic poet in the time of National Revivalist writing allows him to stand out among other Czech poets. It is his ability to use Byronic mechanisms in his poetry in such a way as to promote the cause of the nation that grants him the title of being both a Romantic and Nationalist poet. Mácha created a world as open as the topography of the Czech lands. The pits and falls of his poetry follow the mountains and valleys of the countryside; his imagery reveals the dreams of a young man jumping between desires of breaking free from his environment and working to protect and enhance that environment. Having chosen the latter, Mácha left as part of his legacy a transformation in Czech literature that is still recognized and honored today, partly because he was one of the few Czech poets to embrace Romanticism, but mostly because in his narrative is a story that can be understood internationally; that story is the 
importance of recognizing one's longings and then making the decision whether or not to fulfill them and how to go about satisfying them.

Mácha's greatness is seen not only because of his rich imagery but also because one is able to recognize another significant poet in his writings. The influences that George Gordon, Lord Byron had on Mácha, as I have already discussed, are important in terms of the Romantic Movement as a whole. The fact that Byron's words translated to a poet living in a land-locked country coming out of Austrian rule shows that the Romantics were successful in their mission to ease the forging of new ground. The heroes in both these narrative poems are one of the people. Although Childe Harold was once a knight and turned his back on his life as such, he embraced the life of the lonely wanderer, fulfilling the dreams that many people could only hope to experience. The Narrator, or as I have argued, the older, more mature Lord Byron, becomes the example for the Romantic poets, as well as their readers. Though the pilgrim first acted recklessly, his experiences remain valuable, and as his return to sea reflects, sometimes one must remove himself from his familiar surroundings in order to become who he was meant to be. Similarly, Mácha's pilgrim is of no particular rank or station (the revelation that the pilgrim is also the poet means little in this context; Mácha also had no rank, as he was the son of a Miller's assistant [Wellek, Mácha and English Literature 149]), yet he is the example to which the Czech people must look when faced with the decision to follow their wants, or serve to answer the needs of the country.

Both of these poets work to show the complicated struggles of the human mind, and neither one promises immediate glory for having the courage to make a life-changing decision. The Romantics could not guarantee success and happiness; what they could 
promise was that the journey one would face in the consideration of his longings is a valuable one, and that his journey will lead to the place he was destined to come to. Childe Harold, the pilgrim, was destined to fail, and Vilém, the bandit, was destined to sin against man and Nature. Ironically, the poets were destined to come to an unexpected end themselves. Byron, died of a fever in Missolonghi, Greece in 1824, waiting to participate in the Greek War of Independence. There is much speculation as to the cause of Karel Hynek Mácha's death, shortly after publishing Máj, and a little over a week before his twenty-sixth birthday in 1836, but his sudden death left the Czech world and the European nation with little more than his greatest work of poetry to remember him by. Though Lord Byron wrote much after Childe Harold's Pilgrimage, it is still considered one of his greatest and most influential works; though Máj was Mácha's final literary work, it is considered his best and its importance still rings true today. 


\section{BIBLIOGRAPHY}

Abrams, Meyer Howard. Natural Supernaturalism, Tradition and Revolution in Romantic Literature. New York: Norton, 1971. Print.

Agnew, Hugh LeCaine. Origins of the Czech National Renascence. Pittsburgh: University of Pittsburgh Press, 1993. Print.

Auty, Robert. "Language and Society in the Czech National Revival." The Slavonic and East European Review. Vol. 35, No. 84 (1956): 241-248. JSTOR. Web. 09 Feb 2009.

Beatty, Bernard. "Byron and the Eighteenth Century." The Cambridge Companion to Byron. Bone, Drummond, Ed. Cambridge: Cambridge University Press, 2004. 236-248. Print.

Berlin, Isaiah. The Roots of Romanticism. Ed. Henry Hardy. Princeton: Princeton University Press, 1999. Print.

Blackstone, Bernard. "Byron's Greek Canto: The Anatomy of Freedom.” The Yearbook of English Studies Vol. 4 (1974): 172-189. JSTOR. Web. 02 April 2009.

Bone, Drummond, Ed. The Cambridge Companion to Byron. Cambridge: Cambridge University Press, 2004. Print.

Brinkley, Robert and Hanley, Keith, Eds. Romantic Revisions. Cambridge: Cambridge University Press, 1992. Print.

Byron, George Gordon. "Childe Harold's Pilgrimage." Lord Byron: The Major Works. Ed. Jerome J. McGann. New York: Oxford University Press, Inc., 1986. 19-206. Print.

---. “Don Juan.” Lord Byron: The Major Works. Ed. Jerome J. McGann. New York: Oxford University Press, Inc., 1986. Print.

--.. "Famous In My Time": Byron's Letters and Journals, Volume 2: 1810-1812. Ed. Marchand, Leslie A. Cambridge, MS: The Belknap Press of Harvard University Press, 1973. Print.

---. "In My Hot Youth": Byron's Letters and Journals, Volume 1: 1798-1810. Ed. Marchand, Leslie A. Cambridge, MS: The Belknap Press of Harvard University Press, 1973. Print. 
DePorte, Michael V. "Byron's Strange Perversity of Thought." Modern Language Quarterly Vol. 33 (1972): 405-419. Literary Criticism Online. Web. 09 Feb 2009.

Donohue, Jr., Joseph W. Dramatic Character in the English Romantic Age. Princeton: Princeton University Press, 1970. Print.

Fletcher, George P. Romantics at War: Glory and Guilt in the Age of Terrorism. Princeton: Princeton University Press, 1997. Print.

Folkenflik, Robert. "The Artist as Hero in the Eighteenth Century." The Yearbook of English Studies. Vol. 12, Heroes and the Heroic Special Number (1982): 91-108. JSTOR. Web. 25 February 2009.

Garber, Frederick. "Self, Society, Value and the Romantic Hero." Comparative Literature. Vol. 19, No. 4 (Autumn, 1967): 321-333. JSTOR. Web. 30 March 2009.

Goode, Clement T. George Gordon, Lord Byron: A Comprehensive Annotated Bibliography of Secondary Materials in English, 1973-1994. Lanham: Scarecrow Press, 1997. Print.

Guall, Marilyn. English Romanticism: The Human Context. New York: W.W. Norton and Company, 1988. Print.

Lass, Andrew. "Romantic Documents and Political Monuments: the MeaningFulfillment of History in $19^{\text {th }}$ Century Czech Nationalism". American Ethnologist Vol. 15 (1988): 456-471. Print.

Lindenberger, Herbert. "The Idyllic Moment: On Pastoral and Romanticism." College English. Vol. 34, No. 3 (1972): 335-351. 13 Oct 2008.

Lovejoy, Arthur O. Essays on the History of Ideas. Baltimore: The Johns Hopkins University Press, 1948. Print.

Mácha, Karel Hynek. Máj. Trans. James Naughton. New York: Oxford University Press, 2000. Oxford University Computing Services. Web. 26 March 2008.

Marchand, Leslie A. Byron; a Biography. New York: Knopf, 1957. Print.

Martin, Phillip W. "Heroism and History: Childe Harold I and II and the Tales." The Cambridge Companion to Byron. Bone, Drummond, Ed. Cambridge: Cambridge University Press, 2004. 77-98. Print.

McGann, Jerome J., "Chronology." Lord Byron: The Major Works. New York: Oxford University Press, 1986. xxiv-xxvi. Print. 
--. Ed. Historical Studies and Literary Criticism. Madison: University of Wisconsin Press, 1985. Print.

---. "Introduction." Lord Byron: The Major Works. New York: Oxford University Press, 1986. xi-xxiii. Print.

---. The Romantic Ideology: A Critical Investigation. Chicago: University of Chicago Press, 1983. Print.

Mellor, Anne K. "Byron: 'Half Dust, Half Deity'." English Romantic Irony. Cambridge: Harvard University Press, 1980. 31-76. Print.

---. "Romanticism, Difference and the Aesthetic." Pacific Coast Philology. Vol. 34, No. 2, Convention Program Issue (1999): 127-141. JSTOR. Web. 25 February 2009.

---. "The Paradigm of Romantic Irony." English Romantic Irony. Cambridge: Harvard University Press, 1980. 3-30. Print.

Naughton, James. Eastern and Central Europe. Lincolnwood: Passport Books 1996. Print.

O'Brien, Kathleen. "Romanticism and Rhetoric: A Question of Audience." Rhetoric Society Quarterly. Vol. 30, No. 2 (2000): 77-91. JSTOR. Web. 13 Oct 2008.

Russell, Bertrand. "Byron and the Modern World." Journal of the History of Ideas. Vol. 1, No. 1 (Jan. 1940): 24-37. JSTOR. Web. 30 March 2009.

Součkova, Milada. "Romanticism Gives Birth to Czech Literature." The Czech Romantics. The Hague, Netherlands: Mouton and Co. Publishers, 1958. Print.

---. "The Romantic Waste-Land: K. H. Mácha." The Czech Romantics. The Hague, Netherlands: Mouton and Co. Publishers, 1958. Print.

Taylor, Charles. Sources of the Self: the Making of a Modern Identity. Cambridge, MS: Harvard University Press, 1989. Print.

Thorslev, Peter L., Jr. The Byronic Hero: Types and Prototypes. Minneapolis: University of Minnesota Press, 1965. Print.

Trumpener, Katie. Bardic Nationalism: The Romantic Novel and the British Empire. Princeton: Princeton University Press, 1997. Print.

Volek, Bronislava. "Expressive Elements in Mácha's May and in His Diary and Letters." The Slavic and East European Journal Vol. 34, No. 3 (1990): 348-362. JSTOR. Web. 26 Jan 2009. 